OPEN ACCESS

Edited by:

Ilaria Corsi,

University of Siena, Italy

Reviewed by:

Sumit Ghosh,

The Research Institute at Nationwide Children's Hospital, United States Xiaoxia Dai,

Xi'an Jiaotong University, China

*Correspondence:

Mingwei Zhang

mwzhh@vip.tom.com

Specialty section:

This article was submitted to

Biosafety and Biosecurity,

a section of the journal Frontiers in Bioengineering and

Biotechnology

Received: 07 May 2021 Accepted: 21 September 2021

Published: 02 November 2021

Citation:

Muhammad Z, Ramzan R, Zhang R, Zhao $D$, Gul $M$, Dong $L$ and Zhang $M$ (2021) Assessment of In Vitro and In Vivo Bioremediation Potentials of Orally

Supplemented Free and

Microencapsulated Lactobacillus acidophilus KLDS Strains to Mitigate

the Chronic Lead Toxicity.

Front. Bioeng. Biotechnol. 9:698349.

doi: 10.3389/fbioe.2021.698349

\section{Assessment of In Vitro and In Vivo Bioremediation Potentials of Orally Supplemented Free and Microencapsulated Lactobacillus acidophilus KLDS Strains to Mitigate the Chronic Lead Toxicity}

\author{
Zafarullah Muhammad ${ }^{1}$, Rabia Ramzan ${ }^{2}$, Ruifen Zhang ${ }^{1}$, Dong Zhao ${ }^{1}$, Mehak Gul ${ }^{3}$, \\ Lihong Dong ${ }^{1}$ and Mingwei Zhang ${ }^{1 *}$
}

\begin{abstract}
${ }^{1}$ Key Laboratory of Functional Foods, Ministry of Agriculture and Rural Affairs/Guangdong Key Laboratory of Agricultural Products Processing, Sericultural \& Agri-Food Research Institute, Guangdong Academy of Agricultural Sciences, Guangzhou, China,

${ }^{2}$ College of Food Science and Technology, Huazhong Agricultural University, Wuhan, China, ${ }^{3}$ Shaikh Khalifa Bin Zayed Al-Nahyan Medical \& Dental College, Lahore, Pakistan
\end{abstract}

Lead $(\mathrm{Pb})$ is a pestilent and relatively nonbiodegradable heavy metal, which causes severe health effects by inducing inflammation and oxidative stress in animal and human tissues. This is because of its significant tolerance and capability to bind $\mathrm{Pb}(430 \mathrm{mg} / \mathrm{L})$ and thermodynamic fitness to sequester $\mathrm{Pb}$ in the Freundlich model $\left(R^{2}=0.98421\right)$ in vitro. Lactobacillus acidophilus KLDS1.1003 was selected for further in vivo study both in free and maize resistant starch (MRS)-based microencapsulated forms to assess its bioremediation aptitude against chronic $\mathrm{Pb}$ lethality using adult female BALB/c mice as a model animal. Orally administered free and microencapsulated KLDS 1.1003 provided significant protection by reducing Pb levels in the blood (127.92 \pm 5.220 and $101.47 \pm$ $4.142 \mu \mathrm{g} / \mathrm{L})$, kidneys $(19.86 \pm 0.810$ and $18.02 \pm 0.735 \mu \mathrm{g} / \mathrm{g})$, and liver $(7.27 \pm 0.296$ and $6.42 \pm 0.262 \mu \mathrm{g} / \mathrm{g}$ ). MRS-microencapsulated KLDS 1.0344 improved the antioxidant index and inhibited changes in blood and serum enzyme concentrations and relieved the $\mathrm{Pb}$-induced renal and hepatic pathological damages. SEM and EDS microscopy showed that the $\mathrm{Pb}$ covered the surfaces of cells and was chiefly bound due to the involvement of the carbon and oxygen elements. Similarly, FTIR showed that the amino, amide, phosphoryl, carboxyl, and hydroxyl functional groups of bacteria and MRS were mainly involved in $\mathrm{Pb}$ biosorption. Based on these findings, free and microencapsulated $L$. acidophilus KLDS 1.0344 could be considered a potential dietetic stratagem in alleviating chronic $\mathrm{Pb}$ toxicity.

Keywords: probiotics, L. acidophilus, maize resistant starch, microencapsulation (MC), oral supplementation, $\mathrm{Pb}$ toxicity, in vitro kinetic modeling, in vivo detoxification 


\section{INTRODUCTION}

The ever-increasing population and extensive utilization of conventional and nonconventional sources pollute the environment and pose a severe threat to human health (Kumar et al., 2020). Heavy metals are continuously being accumulated in the atmosphere, especially in food and water, due to industrial expansion (Ali and Khan, 2019; Wu et al., 2021), smelting, synthetic compounds production, mining operations, inappropriate waste disposal, agricultural manure (Gomiero, 2018), pesticides, airplanes, cosmetics, hair dyes, leaded gasoline of vehicles (Singh Sankhla et al., 2021), ceramics, water pipes, solders, Ayurvedic drugs, and canning and packaging of food materials and equipment (Sun et al., 2021). The provoked lethality in all living species is owing to the nonbiodegradability and accumulation of these metals into the food chain (Kang et al., 2016). Altered biochemical and physiological characteristics, and oxidative stress are the concerned mechanisms of heavy metal toxicity in humans (NicolásMéndez et al., 2020). According to the recent epidemiological shreds of evidence, the mounting burden of autoimmune and metabolic diseases related to respiration and infant infections on a global scale is thought to be because of heavy metal pollutants (Feng et al., 2020).

Lead $(\mathrm{Pb})$ is a heavy metal that is persistently available in the earth's crust, water, and air (Kabeer et al., 2019; Kumar et al., 2020). It possesses unique properties of low melting point, ductility, softness, and high malleability, due to which it is frequently used in the operations as mentioned above (Ketsela et al., 2020). $\mathrm{Pb}$ is a nonbiodegradable and non-essential heavy metal with 30-35 days of biological half-life in the blood, but it can remain in the skeletal system and brain for years (Maret, 2017; Rodríguez and Mandalunis, 2018). These properties make it a potent heavy metal toxic contaminant, grievously threatening the human health (Specht et al., 2016). According to the IARC (International Agency for Research on Cancer), ATSDR (Agency for Toxic Substances and Disease Registry), and WHO (World Health Organization), lead is the second most hazardous carcinogen in the human population, imposing acute to chronic toxicity even at minute concentrations (Kenny et al., 2020).

The main routes of human exposure to lead are generally gastrointestinal and respiratory tracts and, to some extent, skin (leaded gasoline) (Li L. et al., 2017; Kenny et al., 2020). Depending on the age (faster in young children) and nutritional factors ( $\mathrm{Ca}$, $\mathrm{Zn}, \mathrm{Fe}, \mathrm{Mg}$ deficiency), the deposition of lead takes place in the lungs through the respiratory tract, liver, kidneys, bones, and then enter into systematic circulation (Olawoyin et al., 2018). Imbalanced calcium homeostasis, carcinogenesis, degenerative variations, tissue illnesses, hematological, cardiovascular (Boskabady et al., 2018), renal, reproductive, skeletal, respiratory, and irreversible neurological disorders in kids are the common disorders associated with $\mathrm{Pb}$ toxicity (Taylor and Schniering, 2010; Boskabady et al., 2018). The cell homeostasis is disturbed when $\mathrm{Pb}$ ions replace several bivalent and monovalent cations like $\mathrm{Mg}^{2+}, \mathrm{Ca}^{2+}, \mathrm{Fe}^{2+}$, and $\mathrm{Na}^{+}$, which finally disrupts inflammatory responses, antioxidant mechanisms, and enzyme regulations resulting in oxidative stress (Muhammad et al., 2018). Oxidative stress is caused by $\mathrm{Pb}$ through the production of reactive oxygen species. These ROS are produced by the disturbed metabolisms of bile acids, energy, amino acids, and vitamin E (Liu et al., 2019). The antioxidant defense system is weakened by the depletion of glutathione which affects the functioning of GPX (glutathione peroxidase), SOD (superoxide dismutase), and increases the oxidation of DNA, proteins, and lipids. So, oxidative stress damages the cell membrane and plays an essential role in imparting adverse health effects through $\mathrm{Pb}$ induced toxicity (Chedea et al., 2019; Liu et al., 2019).

Commonly, CaNa2EDTA (calcium disodium versenate) and DMSA (meso-2,3-dimercaptosuccinic acid) are used as chelating agents to treat the $\mathrm{Pb}$ toxicity, and this method is termed as chelating therapy (Li B. et al., 2017; Muhammad et al., 2018). These agents are administered into the body intraperitoneally or subcutaneously, which can precipitate, causing severe side effects. Similarly, these agents relatively lack selectivity. These also chelate the trace elements $(\mathrm{Zn}, \mathrm{Fe}, \mathrm{Mg}$, and $\mathrm{Cu}$ ) that are necessary for the antioxidant system imposing subsequent deficiency of these trace elements (Bayer, 2015; Wei et al., 2019). Likewise, due to efficacy and safety issues, these agents can cause renal toxicity, anorexia, appetite loss, nausea, vomiting, malaise, and skin reactions. High doses and long-term treatment of these agents are not suitable for chronic $\mathrm{Pb}$ toxicity (Shaban et al., 2021). These reasons necessitate the hunting of alternative, natural, efficient, safe, and economical dietary compounds to counteract the chronic $\mathrm{Pb}$ toxicity.

Using microorganisms alone or in combination with natural polymeric compounds to recover and remove the heavy metal cations is termed as biosorption or bioquenching, which could be a potential technique alternative to chelating therapy (Ubando et al., 2021). Because it is claimed to be a promisingly efficient, safe, and economical method compared to the adsorption, ion exchange coagulation, and chelating remediation methods (Beni and Esmaeili, 2020). Some agricultural-based polymeric substances are getting attention as suitable sorption matrices (Baharuddin et al., 2019). Some recent studies have validated their capacity to sequester $\mathrm{Pb}$ levels in tissues and blood to decrease oxidative stress (Jafarpour et al., 2017). Being the most abundant, multifunctional, biocompatible, biodegradable, and economical biopolymer, starch has gained expansive use in the food and pharmaceutical industry (Baharuddin et al., 2019; Priyan et al., 2020). Maize-resistant starch (MRS) is considered to have a compact structure and high amylopectin contents with more excellent resistance to enzymatic hydrolysis (Muhammad et al., 2021). The properties of having greater amylopectin content, surface area, and Werner-type complexes have increased the ability of maize-resistant starch to ligate metal cations with hydroxyl groups of its D-glucose units (Kirn and Lim, 1999; Hoque et al., 2019). Bhat et al. conducted a study to assess the efficiency of potato-resistant starch (PRS) against heavy metals and stated that it could be an effective adsorbent with 78.1\% efficiency against $\mathrm{Pb}$ adsorption (Bhat et al., 2015).

As far as the functional food industry is concerned, safety, quality, and feasibility cannot be compromised while selecting biosorbents (Bhattacharya, 2019; Duan et al., 2020). Due to 
having specificity, low cost, and environmentally friendly and GRAS status, lactic acid bacteria are considered superorganisms to detoxify the dietary toxins for bioquenching (Zanjani et al., 2017; Allam et al., 2018). Several studies revealed that L. crispatus and $L$. acidophilus showed significant activity against heavy metals by producing S-layer proteins (Schär-Zammaretti and Ubbink, 2003; Ubbink and Schär-Zammaretti, 2007). Zhai et al. studied the protective effects of $L$. plantarum to deal with Cd-induced oxidative stress. The results showed a significant reduction in $\mathrm{Cd}$ absorption, accumulation in the intestine, blood and tissues (Zhai et al., 2017). According to Elsanhoty et al., L. acidophilus bacteria were found to be more effective in removing the $\mathrm{Pb}$ ions. Some studies revealed that $\mathrm{LAB}$ has specific membrane structures where the metal ions are passively bound and removed from the body (Elsanhoty et al., 2016; Ojekunle et al., 2017). According to Zhai et al., Li et al., and Muhammad et al., orally administered microencapsulated and nonencapsulated $\mathrm{LAB}$ showed healing effects against $\mathrm{Pb}$-induced oxidative stress and decreased the levels of $\mathrm{Pb}$ from blood and tissues (Zhai et al., 2015; Li B. et al., 2017; Muhammad et al., 2018). Similarly, Al-Wabel et al. and Jafarpour et al. found an effective role of $\mathrm{LAB}$ in increasing the activity of anti-oxidative enzymes to protect the liver and renal tissues (Al-Wabel et al., 2007; Jafarpour et al., 2017). According to the WHO requirements, probiotics $10^{6}-10^{7} \mathrm{CFU} / \mathrm{ml}$ viable bacteria are needed to yield their therapeutic functions on consumption. Microencapsulating these bacteria with natural polysaccharides is the ultimate approach to retain their viability in harsh processing and gastrointestinal conditions (Muhammad et al., 2017, 2018, 2019).

In our recently published study (Muhammad et al., 2021), we integrated resistant starches for the microencapsulation of $L$. acidophilus KLDS 1.1003 and selected maize resistant starch (MRS) microencapsulated bacteria for the present research work. Due to the insufficient availability of natural remedies to cope with the $\mathrm{Pb}$-induced chronic toxicity and adverse effects of chelating agents, there is an urgent need to develop natural strategies based on natural ingredients. Currently, no study is available on the symbiotic therapeutic potential of orally supplemented L. acidophilus 1.1003 microencapsulated with maize resistant starch to deal with chronic lead toxicity. In the present work, an appraisal of $\mathrm{Pb}$ alleviation and biosorption potentials of MRS-microencapsulated and nonencapsulated or free L. acidophilus KLDS 1.1003 has been conducted. Additionally, their symbiotic protective effects on (enzymatic and non-enzymatic) anti-oxidative responses and mechanisms, reduction in intestinal $\mathrm{Pb}$ absorption, $\mathrm{Pb}$ tolerance, $\mathrm{Pb}$ deposition in tissues, and reduction of oxidative stress in hepatic and renal tissues were appraised. Overall, the basic objectives of the present research work were the in vitro and in vivo evaluation of the combined symbiotic protective role and the bioremedial therapeutic role of orally supplemented MRS based microencapsulated and free L. acidophilus KLDS strains of bacteria against induced oxidative stress due to chronic exposure to $\mathrm{Pb}$ (lead) by using the adult female $\mathrm{BALB} / \mathrm{c}$ mice as a model animal.

\section{MATERIALS AND METHODS}

\section{Chemicals and Material Components}

The kit used to determine the $\mathrm{Pb}$ levels from the whole blood samples was (BH 2100 kit). It was purchased from Beijing Bohui Innovation Technology Co., Ltd. All other kits were acquired from Nanjing Jiancheng Bioengineering Institute (Nanjing, China). These kits include Njjcbio C009 which was used to determine ALT (alanine aminotransferase), and Njjcbio C010 was used to determine AST (aspartate aminotransferase). Similarly, Njjcbio A001 and Njjcbio A003 kits were used to determine SOD (superoxide dismutase) and $\mathrm{MDH}$ (malondialdehyde), respectively. Likewise, Njjcbio A005 was used to determine the GSH-Px (GSH peroxidase), and Njjcbio A006 was used for GSH (glutathione). And Njjcbio A007 kit was used to determine CAT (catalase) activity. $\delta$-Aminolevulinic acid and maize-resistant starch (CAS: 9005-25-8) were procured from Sigma Aldrich (Mainland, China). Lead nitrate and all other reagents used in the experiments were of analytical grade and procured from Jinan Boss Chemical Company (Jinan, China).

\section{Cultures and Bacterial Strains}

L. acidophilus KLDS strains (KLDS 1.0901, 1.902, 1.1003, $\mathrm{AD}_{3}, \mathrm{~L}_{2}$ and $\mathrm{L}_{6}$ ) were isolated from the traditional yogurt products in the Inner Mongolian region of China. After 16S rRNA gene similarity and API 50CH strip analyses, these strains were stored at the KLDS laboratory administered by the Ministry of Education, China. Reactivation of the frozen stock culture of L. acidophilus strains was done two times in de Man, Rogosa and Sharpe agar or the MRS broth, incubation of bacterial strains was carried out at $37^{\circ} \mathrm{C}$ until the stationary phase was reached. Then, the collection of cell pellets was done by centrifuging samples at $10,000 \times \mathrm{g}$ for $10 \mathrm{~min}$ at $4^{\circ} \mathrm{C}$ and using a 21 micro centrifuge (Thermo Sorvall Legend Micro). Sterilized distilled water was used for pellet suspension, but before the suspension, the pellets were washed thrice.

\section{$\mathrm{Pb}$ Tolerance and Binding Capacity Assessment of Bacterial Strains}

The tolerance and binding capability of six L. acidophilus strains (KLDS 1.0901, 1.902, 1.1003, $\mathrm{AD}_{3}, \mathrm{~L}_{2}$, and $\mathrm{L}_{6}$ ) were carried out using a minutely modified and previously described method by Li B. et al. (2017). The biomass was cultivated after $16 \mathrm{~h}$ of incubation and centrifugation for $10 \mathrm{~min}$ at $4^{\circ} \mathrm{C}$ and $10,000 \times$ g. The centrifuged biomass was washed twice with purified water, and the cell pellets were collected afterward. Then, $100 \mathrm{mg} / \mathrm{L}$ of lead nitrate was taken in distilled water, and a bacterial concentration (wet weight) was set to $1 \mathrm{~g} / \mathrm{L}$ in the same water. Later, the bacterial mass and lead nitrate mixed solution was incubated at $37^{\circ} \mathrm{C}$ for the period of $24 \mathrm{~h}$. After incubation, the samples were centrifuged at 10,000 $\mathrm{g}$ for $20 \mathrm{~min}$. After subsequent centrifugation, the supernatants were analyzed to determine the residual $\mathrm{Pb}$ concentrations in the supernatants. A flame atomic absorption spectrophotometer (Spectra AA 220; Varian, Palo Alto, CA, United States) was used for the purpose, and the 
metal removal efficiency was calculated with the following equation (Eq. 1).

$$
\operatorname{Removal}(\%)=\frac{C_{i-} C_{e}}{C_{i}} \times 100
$$

Here, $\mathrm{C}_{e}$ represents the post-removal residual $\mathrm{Pb}$ concentration and $\mathrm{C}_{i}$ denotes the post-removal initial $\mathrm{Pb}$ concentration. The lead $(\mathrm{Pb})$ tolerance of each strain was determined by implicating the minimum inhibitory concentration approach or MIC as described by Gupta et al. (2012) and Zhai et al. (2015). First of all, the MRS agar medium was prepared with the lead nitrate $(100-1,000 \mathrm{mg} / \mathrm{L})$ solution. The cultured LAB strains $(10 \mu \mathrm{L})$ were spread separately on the MRS agar medium by taking the $1 \times 10^{9} \mathrm{CFU} / \mathrm{ml}$ inoculum. Later on, the inoculated plates were incubated at $37^{\circ} \mathrm{C}$ for $48 \mathrm{~h}$ and determined the LAB strains growth. The minimum $\mathrm{Pb}$ concentration, which entirely repressed the growth of LAB strains, was taken as the MIC for the present research work.

\section{Equilibrium Isotherm}

The equilibrium isotherm study was carried out by following the method described by Chakarvarty et al. (Chakravarty and Banerjee, 2012). According to this method, lead nitrate (5-60 mg/L) containing ultrapure water was used to suspend the harvested cell pellets and dry weight $(1 \mathrm{~g} / \mathrm{L})$-based final bacterial concentration was prepared. The initial $\mathrm{pH}$ for the $\mathrm{Pb}$ binding assay was taken as 6.0, and the bacterium bound $\mathrm{Pb}$ equilibrium content was determined by the following Eq. 2 .

$$
\mathrm{Q}_{\mathrm{e}}(\mathrm{mg} \text { metal } / \mathrm{g} \text { biosorbent })=\frac{C i-\mathrm{Ce}}{m / V}
$$

where $\mathrm{C}_{i}$ denotes the post-removal initial $\mathrm{Pb}$ concentration, and $\mathrm{C}_{e}$ represents the post-removal residual $\mathrm{Pb}$ concentration, respectively, whereas $\mathrm{m} / \mathrm{V}=1 \mathrm{~g} / \mathrm{L}$. The determination of sorption equilibrium between the metal ions and biosorbents was carried out using the Langmuir and Freundlich models, and nonlinear regression methods were used to obtain isotherm constants for the models (Khayyun and Mseer, 2019).

\section{Microencapsulation of Bacterial Strain, Survival After In Vitro Digestion and Storage}

L. acidophilus KLDS 1.1003 were microencapsulated by using maize-resistant starch-based formulations. And the process of spray-dried microencapsulation was carried out using Buchi B290 (Flawil, Switzerland) lab-scale spray dryer. The appraisal of probiotic's survival during in vitro digestion and storage was done following the previously reported method in our formerly published research article (Muhammad et al., 2017, 2018). According to our previous study, maize-resistant starch (MRS) based formulations provided the best protection to probiotic strains during spray-dried microencapsulation, in vitro digestion, and storage. Similarly, L. acidophilus KLDS 1.1003 has shown highest $\mathrm{Pb}$ binding capability as compared to other KLDS strains, so MRS-based microencapsulated KLDS 1.1003 was selected as the best suitable strain for mice model experiments. The microencapsulated bacterial strains were lyophilized by mixing with skimmed milk and stored at $-20^{\circ} \mathrm{C}$. Skimmed milk acts as a cryoprotectant agent and protects lyophilized bacterial cells against below freezing temperature. The viability of the freeze-dried bacterial cells was done by colony counting, before conducting the animal model experiments. Briefly, the reactivation of freeze-dried bacterial cells by using distilled water was carried out. The documented bacterial cells viability was calculated as $2.7 \times 10^{9} \mathrm{CFU} / \mathrm{ml}$. During the experimentation period, the reactivated lyophilized probiotic bacteria were mixed in skimmed milk through oral gavage to each mice by taking the oral dose of $0.5 \mathrm{ml}$ conforming to almost $1.3 \times 10^{9} \mathrm{CFU}$ of microencapsulated KLDS 1.1003.

\section{Scanning Electron Microscopy Analyses of Untreated and $\mathrm{Pb}$ Treated Bacteria}

The preparation of SEM samples was done by following the method described by Wang et al. (2017). 2.5\% glutaraldehyde (v/ v) was used to fix the harvested cell pellets, which were $\mathrm{Pb}$ treated $(60 \mathrm{mg} / \mathrm{L})$ and untreated. This fixing process was carried out at $4^{\circ} \mathrm{C}$ for $1.5 \mathrm{~h}$, and the pellets were washed with phosphate buffer solution three times. After discarding the supernatants, the treatment of cell pellets with alcohol was done. A mixture of t-butanol and alcohol (1:1) with 50, 70, 90, and 100\% alcohol concentrations were used for successive washing of cell pellets. Lastly, the elution of cell pellets was done with plain t-butanol. After elution, the samples were freeze-dried for $4 \mathrm{~h}$ and then sputter coated with gold. The scanned micrographic photographs were taken by using SEM, coupled with EDS or an energy dispersive spectrometer.

\section{FT-IR Analyses}

FT-IR analyses of the untreated and $\mathrm{Pb}$ treated cell pellets were carried to analyze the changes in the functional groups of these treatments. These untreated and $\mathrm{Pb}$ treated $(60 \mathrm{mg} / \mathrm{L})$ harvested cell pellets were freeze-dried and then mixed with potassium bromide $(\mathrm{KBr})$ powder to prepare $\mathrm{KBr}$ discs. These $\mathrm{KBr}$ discs contained a finely ground powder $(2 \% \mathrm{w} / \mathrm{w})$ of each sample.

\section{In Vivo Evaluation of Free and Microencapsulated $L$. acidophilus KLDS1.1003 Promises Countering Induced Chronic $\mathrm{Pb}$ Toxicity \\ Animal Experiment}

Adult female BALB/c mice were obtained from the Huazhong Agricultural University (Animal Center, Wuhan, China). The mice were housed in a well-managed room with controlled temperature $\left(25^{\circ} \mathrm{C}\right)$, the environment with standard dark and light cycles $(12 \mathrm{~h}$ light-dark cycle). Well-designed stainless steel cages were used to keep the mice, and a free supply of commercially available standard mice food was given throughout the trial. The ad libitum sterilized water supply was also managed, and $\mathrm{Pb}$ free and $\mathrm{Pb}$ contaminated water was supplied to the therapy groups. The approved protocols by the Ethics Committee of Guangdong Academy of Agricultural Sciences and Guangdong provincial Animal Care Committee, Guangzhou, China, were strictly followed during the trial. Also, 
TABLE 1 | Protocols for the animal experiment.

\section{Groups}

Non lead exposed

\section{$\mathrm{C}+\mathrm{ve}$}

Free L. acidophilus KLDS 1.1003

MRS-based encapsulated L. acidophilus KLDS 1.1003

C -ve

Free L. acidophilus KLDS 1.1003+lead

MRS-based encapsulated L. acidophilus KLDS 1.1003+lead

\section{Feeding plan}

\section{$\mathrm{SM}+\mathrm{PW}$}

$\mathrm{SM}+\mathrm{PW}+\mathrm{KLDS}$ KLDS 1.1003

$\mathrm{SM}+\mathrm{PW}+$ encapsulated KLDS 1.1003

$\mathrm{SM}+\mathrm{Pb}$ (in drinking water)

$\mathrm{SM}+\mathrm{Pb}$ (in drinking water)+KLDS 1.1003

$\mathrm{SM}+\mathrm{Pb}$ (in drinking water)+encapsulated KLDS 1.1003

Note: Skimmed milk (SM) daily $0.5 \mathrm{ml}$ through gavage; plain drinking water (PW); Pb (in drinking water), lead nitrate at $100 \mathrm{mg} / \mathrm{L}$ (in drinking water); and SM+free and MRS-based encapsulated KLDS 1.1003, $1.4 \times 10^{9} \mathrm{CFU}$ L. acidophilus KLDS 1.1003 in skimmed milk (SM) daily $0.5 \mathrm{ml}$ through gavage. The experimental treatments lasted for 7 weeks.

the methods used during the study were followed in accordance with the recommended guidelines of the European Community to handle the animals that are used for experimental trials (directive 2010/63/EU). The mice were kept for 1 week without giving any treatment to adapt to the environmental conditions.

The group division of mice is given in Table 1. Six subgroups of mice were taken, with ten mice in each group as follows: $\mathrm{C}+\mathrm{ve}$ (control with no $\mathrm{Pb}$ or KLDS 1.1003), $\mathrm{C}-\mathrm{ve}$ ( $\mathrm{Pb}$ only), free Lactobacillus acidophilus KLDS 1.1003 only, MRS based microencapsulated Lactobacillus acidophilus KLDS 1.1003 only, $\mathrm{Pb}$ plus free Lactobacillus acidophilus KLDS 1.1003, and $\mathrm{Pb}$ plus encapsulated Lactobacillus acidophilus KLDS 1.1003. The oral dose of $1.3 \times 10^{9} \mathrm{CFU}$ of Lactobacillus acidophilus KLDS 1.1003 mixed in $0.5 \mathrm{ml}$ of skimmed milk was gavage fed to the mice of therapy groups. The oral dose was given once a day/every day during the trial period. The oral dose of $\mathrm{Pb}$ was prepared by mixing lead nitrate $(100 \mathrm{mg} / \mathrm{L})$ in sterilized water. This dose was selected based on the average $\mathrm{Pb}$ concentration to which humans are environmentally exposed in $\mathrm{Pb}$ polluted areas (Muhammad et al., 2018). This leadcontaminated water was given to the mice groups in order to expose them to the induced chronic lead toxicity. During this trial, the body weights were measured every week.

Similarly, the fecal samples of each group were also collected weekly. Before fecal collection, the mice were transferred to separate cages for 1 hour. At the end of the 7 th week, the individual transfer of mice was carried out in metabolic cages, and animals were kept in these cages for $24 \mathrm{~h}$. After $24 \mathrm{~h}$ stay, the blood samples were collected from the eye balls of the mice by using the heparinized tubes to get plasma from these samples. Moreover, redtop plastic tubes were used to collect the blood samples for the serum analyses.

Afterward, the livers and kidneys were removed from the mice bodies and these organs were washed with sterile normal saline solution with a concentration of $0.9 \% \mathrm{NaCl}$. The saline solution was simply prepared by mixing sterilized water and $\mathrm{NaCl}$. After washing, the samples were preserved in $10 \%$ formalin saline for 2 days and then, the histopathological study was carried out. Extra samples of kidneys and livers were put into cryotubes and stored at $-80^{\circ} \mathrm{C}$ after wrapping them with the aluminum foil in order to post the scarifying assessment of biochemical assays and chemical elements (Hasanein and Emamjomeh, 2019).

\section{Assessment of Chemical Elements in Tissues}

The measurement of essential metals in the tissue samples was done by digesting them in Omni: CEM (United Kingdom) manufactured metal-free digestion vessels. Concentrated nitric acid was used for sample digestion, and MARS: CEM (United Kingdom) manufactured microwave digestion system was used for the purpose. The metal ( $\mathrm{Ca}, \mathrm{Mg}, \mathrm{Zn}$, and $\mathrm{Fe}$ ) quantities in the liver and kidney samples were measured. Metal quantification was done with a flame atomic absorption spectrophotometer (AAS) or graphite furnace (Meucci et al., 2020).

\section{Quantification of Lead $(\mathrm{Pb})$ in Whole Blood Samples, Liver and Kidney Tissues}

The $\mathrm{Pb}$ levels in whole blood samples were measured by using a BH 2100 kit. The measurement of essential metals in the tissue samples was done by digesting them in Omni: CEM (United Kingdom) manufactured metal-free digestion vessels. Concentrated nitric acid was used for sample digestion, and MARS: CEM (United Kingdom) manufactured microwave digestion system was used for the purpose. The $\mathrm{Pb}$ quantities in the liver and kidney samples were measured. $\mathrm{Pb}$ quantification was done with a flame atomic absorption spectrophotometer (Specter. AA; Varian or AAS). The representative units for lead measurement in blood and tissues are given as $\mu \mathrm{g} / \mathrm{L}$ and $\mu \mathrm{g} / \mathrm{g}$, respectively (Dobrakowski et al., 2016; Meucci et al., 2020).

\section{Biochemical Assays}

The kits used for the assays are given in brackets in front of each biochemical assay. These biochemical assays include, GSH-Px (Njjcbio A005), GSH (Njjcbio A006), SOD (Njjcbio A001), and CAT (Njjcbio A007) activities and MDH (Njjcbio A003), GSH (Njjcbio A006) levels in tissues and ALT (Njjcbio C009), AST (Njjcbio C010) activities in serum. These kits were procured from the Nanjing Jiancheng Bioengineering Institute (Nanjing, China), and the guidelines of the kit manufacturing company were followed for all the biochemical assays, and all assays were done thrice (Dobrakowski et al., 2016; Yu et al., 2017).

\section{Histopathological Studies}

Histopathological studies were carried out after keeping the tissue (liver and kidney) samples for $48 \mathrm{~h}$ in $10 \%$ formalin. Before analyses, these organs were washed with double distilled $\left(\mathrm{ddH}_{2} \mathrm{O}\right)$ or ultrapure water and dehydrated. A rotary microtome was used to cut the paraffin-embedded samples of $5 \mu \mathrm{m}$ thickness. These $5 \mu \mathrm{m}$ slices were then stained with $\mathrm{H} \& \mathrm{E}$ (haematoxylin-eosin) dyes, and optical microscopic analyses were done (Li B. et al., 2017; Yu et al., 2017; Muhammad et al., 2018). 
TABLE 2 | Pb tolerance and binding ability of the tested Lactobacillus acidophilus KLDS strains.

Strains

L. acidophilus KLDS1.0901

L. acidophilus KLDS 1.0902

L. acidophilus KLDS 1.1003

L. acidophilus KLDS $\mathrm{AD}_{3}$

L. acidophilus KLDS $L_{2}$

L. acidophilus KLDS $L_{6}$
Lead removal by

wet biomass (\%)

$45.28^{\mathrm{e}}$

$64.36^{\mathrm{b}}$

$76.20^{\mathrm{a}}$

$48.37^{f}$

$54.61^{d}$

$62.00^{c}$
Minimum inhibitory concentration for $\mathrm{Pb}(\mathrm{mg} / \mathrm{L})$

$300.00 \pm 2.42^{b}$

$170.00 \pm 1.73^{d}$

$430.00 \pm 0.32^{a}$

$230.00 \pm 0.31^{\mathrm{c}}$

$58.00 \pm 0.12^{f}$

$33.00 \pm 5.64^{\mathrm{e}}$

Incubation was done with an initial $\mathrm{Pb}$ nitrate concentration of $100 \mathrm{mg} / \mathrm{L}$. Values are mean $\pm \mathrm{SD}$ of three determinations. Different letters indicate the significant differences ( $\mathrm{p}<0.05)$ among the strains.

TABLE 3 | Adsorption constants derived from simulations with different isotherm models.

\begin{tabular}{lcc}
\hline $\begin{array}{l}\text { Name } \\
\text { of isotherm model }\end{array}$ & Constant & Value \\
\hline Langmuir isotherm & & \\
$1 / q e=1 /$ KLqmax $1 /$ Ce+1/qmax & $\mathrm{q}_{\max }$ & 6.1124 \\
& $\mathrm{~K}_{\mathrm{L}}$ & 0.3204 \\
& $\mathrm{R}_{\mathrm{L}}$ & 0.0587 \\
Freundlich isotherm & $\mathrm{R}^{2}$ & 0.9052 \\
Logqe = Log Kf+1/nLogCe & $1 / \mathrm{n}$ & 1.4118 \\
& $\mathrm{~K}_{\mathrm{f}}$ & 25.8134 \\
& $\mathrm{R}^{2}$ & 0.9842
\end{tabular}

$q_{e}$ (mg metal/g biosorbent) represents the equilibrium content of the Pb bound by the biomass.

$C_{e}(m g / L)$ represents the equilibrium $\mathrm{Pb}$ concentration.

\section{Statistical Analyses}

All experiments were performed thrice to compile the data. The statistical analyses were carried out by Statistics 8.1 (Analytical Software, United States), and the Tukey method was used for the comparison of means and the analysis of variance (ANOVA). Statistically, the values of $p<0.05$ were taken as significant values. All the values are represented as the mean $\pm \mathrm{SD}$.

\section{RESULTS}

\section{Tolerance and $\mathrm{Pb}$ Biosorption of Lab Strains}

Lead $(\mathrm{Pb})$ binding and tolerance abilities of six Lactobacillus acidophilus KLDS strains are given in Table 2. The exhibited $\mathrm{Pb}$ removal range of these tested strains was 45.28-76.20\% (Table 2), whereas the initial $\mathrm{Pb}$ concentration was $100 \mathrm{mg} / \mathrm{L}$. L. acidophilus KLDS 1.1003 showed the highest $\mathrm{Pb}$ binding ability among all the tested strains. Keeping in view of the $\mathrm{Pb}$ binding ability of $L$. acidophilus KLDS 1.1003, it was chosen as the best apposite strain to be studied for further in vivo analyses.

\section{Evaluation of Biosorption and Isotherms Models}

As shown in Figures 1A,B, the concentration of $\mathrm{Pb}$ in the solution has a positive correlation with the $\mathrm{Pb}$-binding ability of $L$. acidophilus KLDS 1.1003. The respective data of different isotherm models, including the Freundnlich and Langmuir models, have been given in Table 3. According to the coefficients of the correlation $\left(R^{2}\right)$ values, it
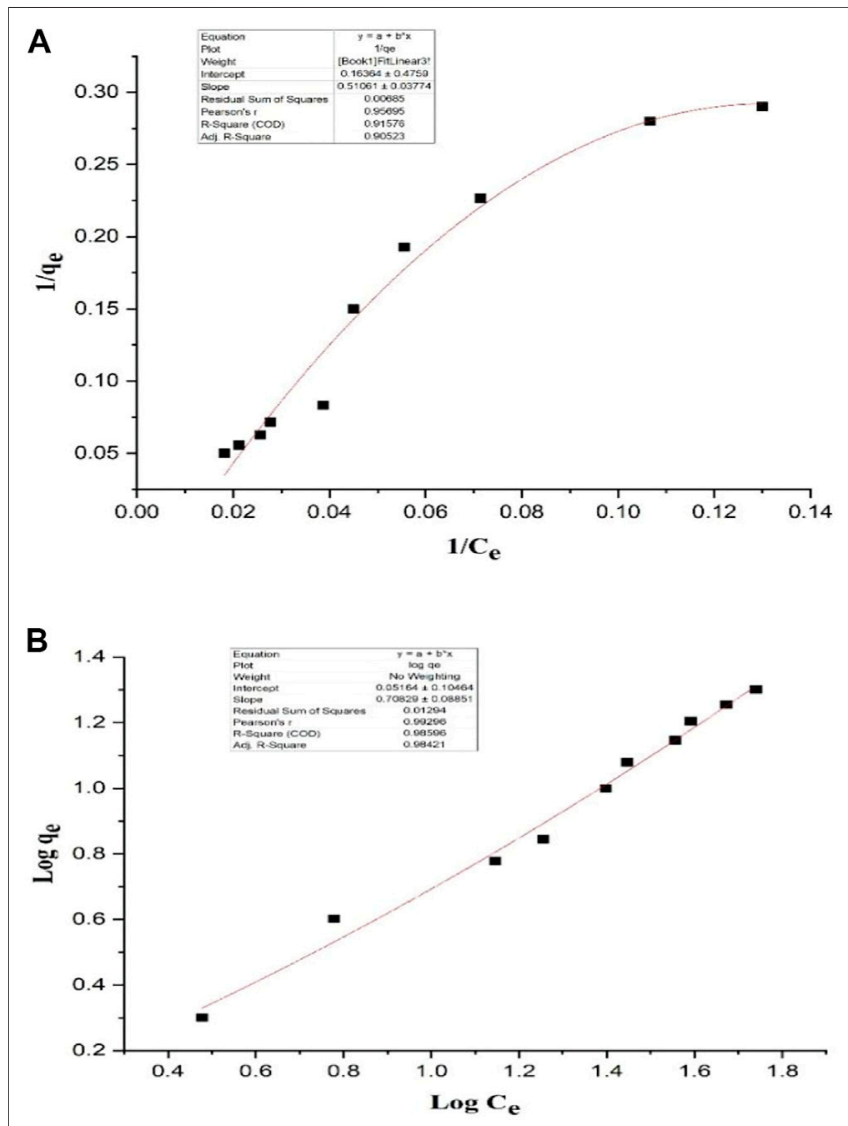

FIGURE 1 | (A, B) Adsorption isotherm of $\mathrm{Pb}$ binding by $\mathrm{L}$. acidophilus KLDS 1.1003.

is clear that the Freundlich model with $R^{2}=0.98421$ is the best suitable model for our experimental data.

In addition, maize-resistant starch (MRS) based microencapsulated L. acidophilus KLDS 1.1003 also indicated the more lead binding capacity followed by free bacteria (Figure 2), and the completion of the binding process was taken place in about $80 \mathrm{~min}$.

\section{Electron Microscopy Analysis}

After the lead $(\mathrm{Pb})$ treatment, the SEM micrographs of free and MRS-microencapsulated L. acidophilus KLDS 1.1003 indicated 


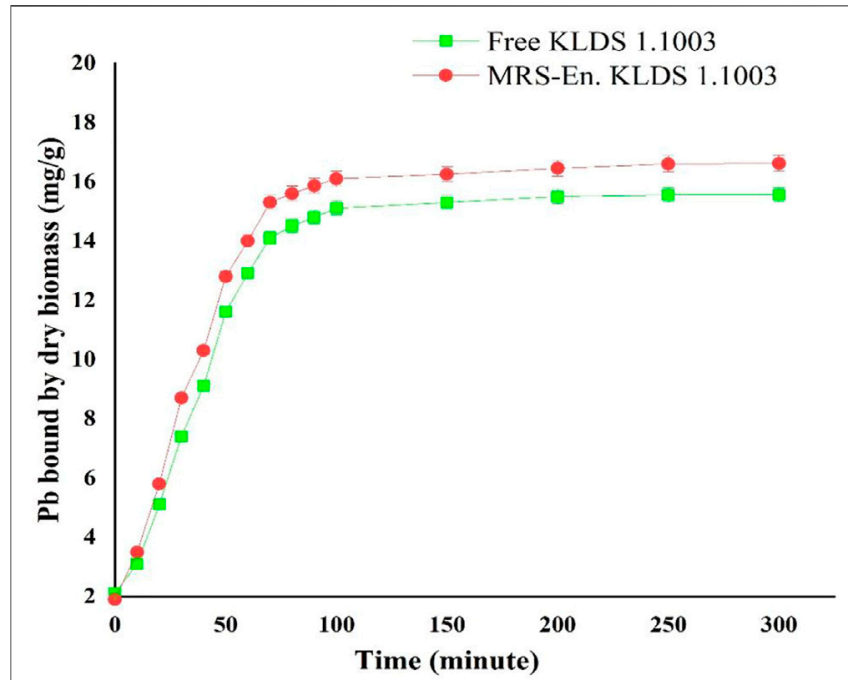

FIGURE 2 | Lead binding of free and MRS-based encapsulated $L$. acidophilus 1.1003 at different time points. Values are mean \pm standard deviation (SD).

that the various light clusters of metal precipitates were present, but these clusters did not show the even coverage of the cell surface (Figures 3C,D). Conversely, the light precipitates were not found on the cell surface of the untreated pellets (Figures
3A,B). Further confirmation of $\mathrm{Pb}$ in the light precipitate was validated by the EDS analysis (data not shown).

\section{FT-IR Analysis}

The FT-IR spectrums of free and MRS-based encapsulated $L$. acidophilus KLDS1.1003 and treated with $\mathrm{Pb}(60 \mathrm{mg} / \mathrm{L})$ are shown in Figure 4. The noticeable shift to a substantial wave number at $3,550-3,100 \mathrm{~cm}^{-1}$ might be owing to the $(-\mathrm{OH})$ group of starch and $\mathrm{Pb}$ interaction, and the desertion of the peak at $18,200-1,720, \quad 1,680-1,660, \quad 1,620-1,590, \quad 1,520-1,480$, $1,400-1,390, \quad 1,250-1,240, \quad 1,220-1,210, \quad 1,170-938$, and $926-541 \mathrm{~cm}^{-1}$ pointed out that the $\mathrm{O}-\mathrm{H}, \mathrm{P}=\mathrm{O}$ or $\mathrm{C}-\mathrm{O}$ broadening of polysaccharide vibrations participated in the $\mathrm{Pb}$ biosorption function of these polymeric materials. Meanwhile, a $\mathrm{C}=\mathrm{O}$ elongating vibration of carboxylic acid was detected in the $2,370-2,320 \mathrm{~cm}^{-1}$ region. Similarly, a strong modification at $2,370-2,320 \mathrm{~cm}^{-1}$ wave number might be because of the $\mathrm{Pb}$ interaction with $-\mathrm{OH}$ group of alcohol-phenol and the $-\mathrm{NH}$ group of amide, respectively. Additionally, the amine II band $\left(1,040-978 \mathrm{~cm}^{-1}\right)$ is linked with broadening the $\mathrm{C}-\mathrm{N}$ peptide bond and $\mathrm{NH}$ in-plane bending mode. These elements could be combined with lead $(\mathrm{Pb})$ by the key functional groups like hydroxyl, phosphoryl, carboxyl, amino and, and amide groups.

\section{Body Weight of Mice}

Keeping in view of the lead $(\mathrm{Pb})$ biosorption capacities and tolerance of the lactic acid bacterial strains, L. acidophilus
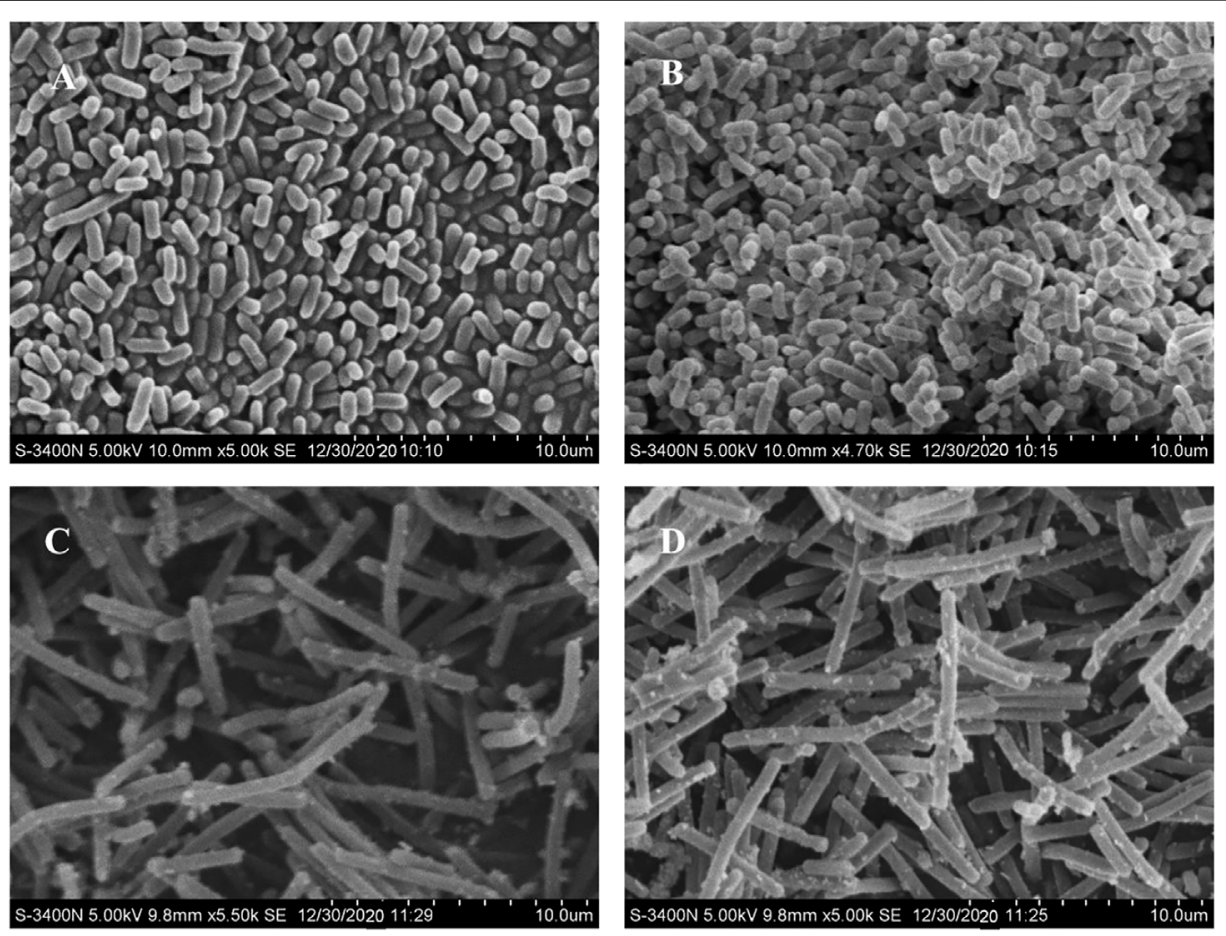

FIGURE 3 | Scanning electron microscopy (SEM) micrographs of free and MRS-based encapsulated L. acidophilus KLDS 1.1003 untreated and treated with Pb (60 mg/L). (A) L. acidophilus KLDS 1.1003 only, (B) MRS-based encapsulated L. acidophilus KLDS 1.1003 only, (C) L. acidophilus KLDS 1.1003 plus lead, (D) MRSbased encapsulated $L$. acidophilus KLDS 1.1003 plus lead. 


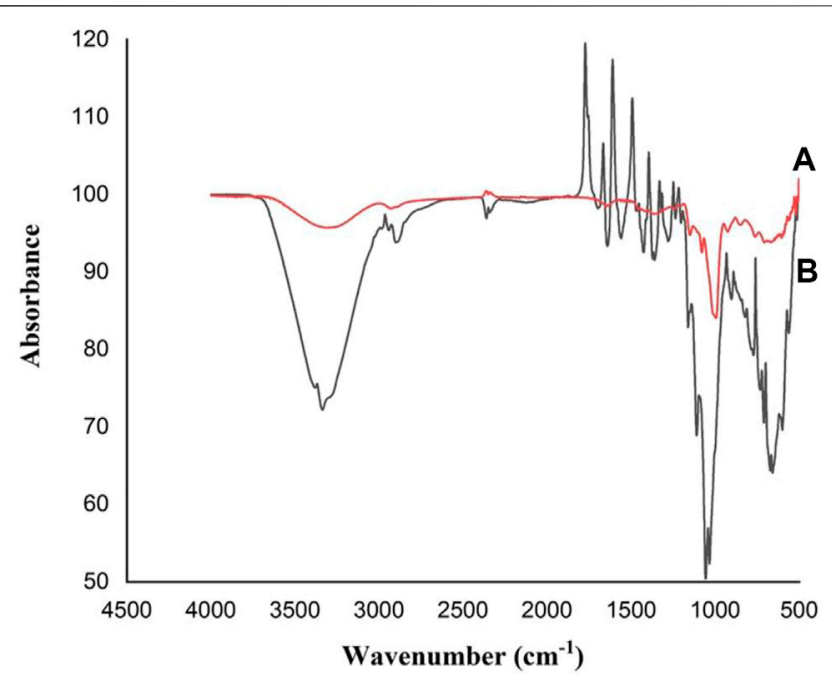

FIGURE 4 | FT-IR or Fourier transform infrared spectrums of $L$. acidophilus KLDS1.1003 free and MRS-based encapsulated with Pb (60 mg/ L): (A) Free L. acidophilus KLDS1.1003 biomass; and (B) MRS-based encapsulated L. acidophilus KLDS1.1003 biomass.

KLDS 1.1003 was selected as the best candidate for assessing its potentiality against lead toxicity in the forms of microencapsulated and free or nonencapsulated bacteria. During the experimentation period of 7 weeks, the weight of each mouse was observed, and it was found that there was no significant difference $(p>0.05)$ among all the studied groups. As shown in Figure 5, maximum bodyweight was witnessed in $\mathrm{C}+\mathrm{ve}$ $27.05 \pm 0.1342 \mathrm{~g}$ succeeded by $27.00 \pm 0.13 \mathrm{~g}$ in the MRS basedmicroencapsulated KLDS $1.1003+\mathrm{Pb}$ group, contrary to the $\mathrm{C}-\mathrm{ve}$ group $(26.62 \pm 0.51 \mathrm{~g})$ at 7 th week of the study.

\section{Lead $(\mathrm{Pb})$ Concentrations in the Kidneys, Liver and Blood}

According to Figure 6, among all the studied groups, the groups which were non-orally exposed to $\mathrm{Pb}$, the $\mathrm{Pb}$ concentrations in the liver, kidneys, and blood were suggestively smaller than the orally exposed lead group $(p<0.05)$. The reduction of $\mathrm{Pb}$ levels in the blood and kidneys of the lead dose groups was significantly different from the observed results of the C-ve group $(p<0.05)$. Compared to the $\mathrm{C}-\mathrm{ve}$ groups, free and MRS microencapsulated L. acidophilus KLDS 1.1003 treatments showed an expressive decrease of the $\mathrm{Pb}$ concentrations in tissues and blood. The $\mathrm{Pb}$ contents in the $\mathrm{C}+\mathrm{ve}$ group tissues, free and MRS encapsulated KLDS 1.1003-only groups were very low in the liver and kidneys $0.25 \pm 0.010 \mu \mathrm{g} / \mathrm{g}, 0.09 \pm 0.003 \mu \mathrm{g} / \mathrm{g}$, and $0.06 \pm 0.002 \mu \mathrm{g} / \mathrm{g}$ respectively, as shown in Figure 6. As compared to the orally exposed C -ve $(21.36 \pm 0.872 \mu \mathrm{g} / \mathrm{g}$ in the liver $23.13 \pm 0.944 \mu \mathrm{g} / \mathrm{g}$ in the kidney), free KLDS $1.1003+$ lead $(7.27 \pm 0.296 \mu \mathrm{g} / \mathrm{g}$ in liver $19.86 \pm 0.810 \mu \mathrm{g} / \mathrm{g}$ in the kidney) and MRS encapsulated KLDS $1.1003+$ lead $(6.42 \pm 0.262 \mu \mathrm{g} / \mathrm{g}$ in the liver $18.02 \pm 0.735 \mu \mathrm{g} / \mathrm{g}$ in the kidney) significantly $(p<0.05)$ reduced the lead $(\mathrm{Pb})$ contents in the kidney and liver tissues of the studied mice. Concentrations of $\mathrm{Pb}$ in mice blood $(\mu \mathrm{g} / \mathrm{L})$ are provided in Figure 6. Contrary to the $\mathrm{C}$-ve group $(142.5 \pm 5.817 \mu \mathrm{g} / \mathrm{L})$, MRS encapsulated $L$. acidophilus KLDS 1.1003+lead showed a considerable $\mathrm{Pb}$ content reduction in tissues and blood $(101.47 \pm 4.142 \mu \mathrm{g} / \mathrm{L})$ by protecting against the toxic effects of $\mathrm{Pb}$ in blood and tissues.

\section{Essential Elements (Ca, Zn, Fe, and Mg) Quantities in the Kidneys and Liver}

During the study, variations in the concentration of essential elements $(\mathrm{Ca}, \mathrm{Mg}, \mathrm{Fe}$, and $\mathrm{Zn}$ ) in the kidneys and liver were observed due to the $\mathrm{Pb}$ exposure. These values are presented in (Table 4). Except for $\mathrm{Zn}$, all other elemental variations in the kidneys and liver were significantly inverted in the free and encapsulated KLDS 1.1003+lead groups $(p<0.05)$. Nonetheless, compared to the $\mathrm{C}$-ve group, a significant increase of the metal levels in the livers of all the other groups was observed.

\section{GSH, GPx, SOD, CAT and MDA in Renal and Hepatic Tissues}

The capacity levels of anti-oxidating enzymes in the mice kidneys and liver have been shown in Table 5. The levels of GSH, SOD, and CAT were significantly decreased when the mice were exposed to lead $(\mathrm{Pb})$ belonging to both non-orally and orally exposed groups. This reduction was due to the chronic exposure of these mice to $\mathrm{Pb}$, while on the other hand, MDA and GSH-Px levels were increased simultaneously. Integration of the MRSbased microencapsulated L. acidophilus KLDS 1.1003 treatment effectually maximized the CAT levels in the liver $(223.89 \pm$ $1.41 \mathrm{U} / \mathrm{mgprot}$ as compared to the $\mathrm{C}$-ve group $112.62 \pm$

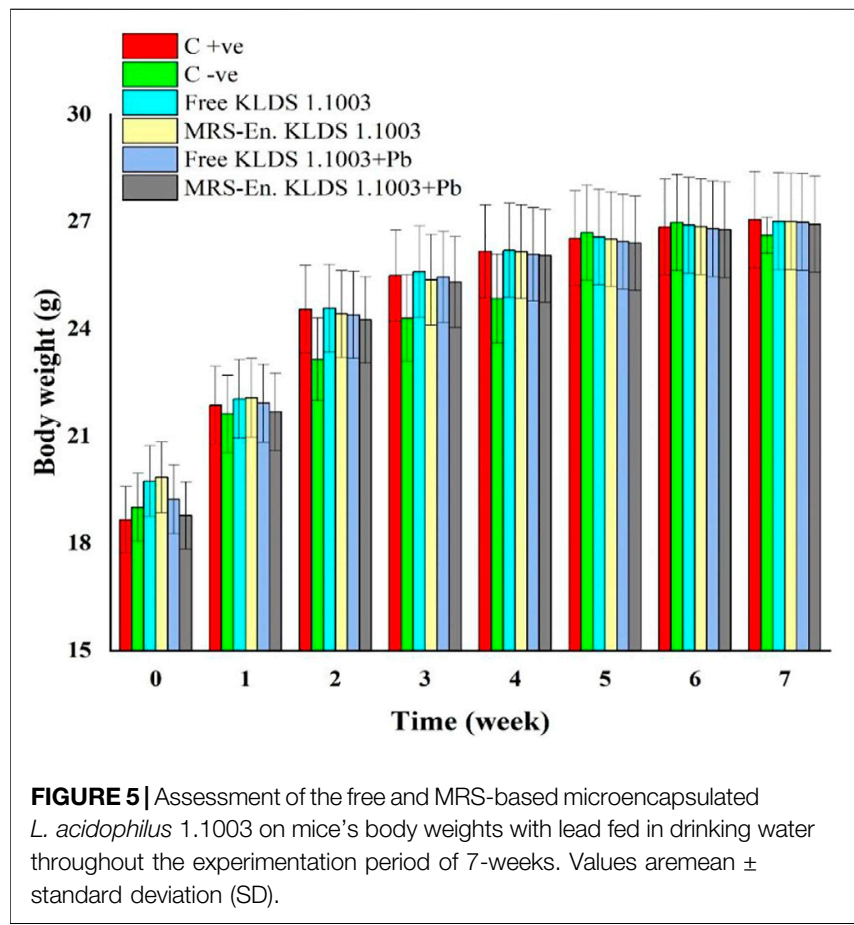




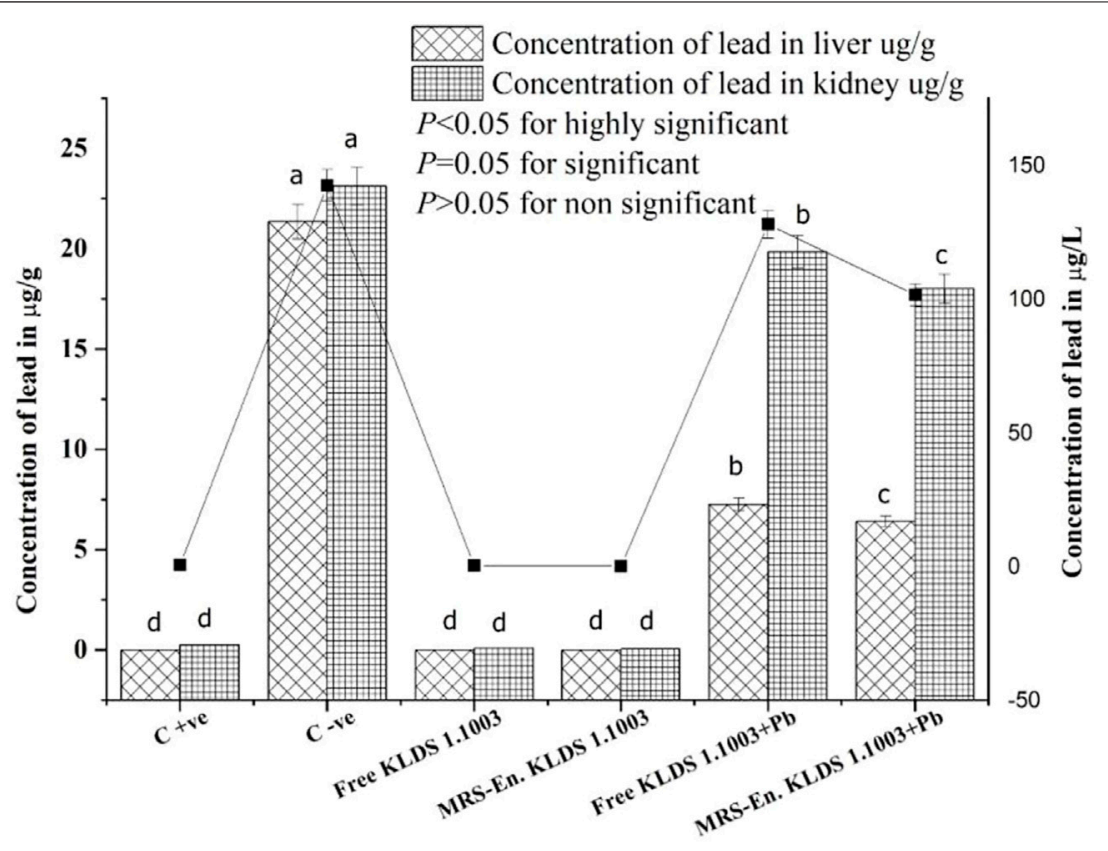

FIGURE 6 | Influence of feeding free and MRS-based encapsulated $L$. acidophilus 1.1003 on the levels of Pb in the blood ( $\mu$ g/ $L$ ) of mice presented with a solid line, in the kidney $(\mu \mathrm{g} / \mathrm{g})$ and liver $(\mu \mathrm{g} / \mathrm{g})$ of mice presented with bar with lead nitrate in drinking water. The significant difference $(p<0.05)$ is shown by letters. Values are mean \pm standard deviation (SD).

TABLE 4 | Effects of nonencapsulated and MRS-based encapsulated L. acidophilus 1.1003 on metal levels in the livers and kidneys of mice.

\begin{tabular}{|c|c|c|c|c|}
\hline $\begin{array}{l}\text { Group } \\
\text { Liver }\end{array}$ & Zn & $\mathbf{C a}$ & Mg & $\mathrm{Fe}$ \\
\hline \multicolumn{5}{|l|}{ Liver } \\
\hline $\mathrm{C}+\mathrm{ve}$ & $27.31 \pm 1.00$ & $300.05 \pm 1.23^{d}$ & $231.11 \pm 0.08^{\mathrm{C}}$ & $79.98 \pm 3.92^{a}$ \\
\hline C-ve & $28.08 \pm 1.41$ & $241.70 \pm 1.33^{\mathrm{e}}$ & $209.22 \pm 2.26^{f}$ & $34.04 \pm 1.72^{\mathrm{e}}$ \\
\hline Free L. acidophilus KLDS 1.1003 & $26.27 \pm 1.31$ & $321.21 \pm 2.03^{b}$ & $230.36 \pm 0.05^{d}$ & $69.53 \pm 3.47^{b}$ \\
\hline MRS-based encapsulated L. acidophilus KLDS 1.1003 & $25.05 \pm 1.25$ & $347.23 \pm 4.29^{a}$ & $248.26 \pm 1.36^{a}$ & $72.01 \pm 3.60^{a, b}$ \\
\hline Free L. acidophilus KLDS 1.1003 + lead & $25.22 \pm 1.26$ & $296.64 \pm 3.02^{f}$ & $219.24 \pm 4.13^{\mathrm{e}}$ & $42.09 \pm 2.10^{d}$ \\
\hline MRS-based encapsulated L. acidophilus KLDS 1.1003 +lead & $24.12 \pm 1.20$ & $303.09 \pm 1.52^{\mathrm{C}}$ & $237.31 \pm 2.02^{b}$ & $46.94 \pm 2.34^{c}$ \\
\hline \multicolumn{5}{|l|}{ Kidney } \\
\hline $\mathrm{C}+\mathrm{ve}$ & $16.92 \pm 0.84$ & $815.22 \pm 3.22^{d}$ & $178.98 \pm 2.11^{f}$ & $52.31 \pm 0.61^{d}$ \\
\hline C -ve & $22.32 \pm 1.11$ & $824.27 \pm 3.09^{c}$ & $202.62 \pm 0.03^{d}$ & $48.29 \pm 2.41^{\mathrm{e}}$ \\
\hline Free L. acidophilus KLDS 1.1003 & $20.28 \pm 1.01$ & $802.02 \pm 2.02^{f}$ & $210.62 \pm 0.11^{b}$ & $59.14 \pm 2.95^{b}$ \\
\hline MRS-based encapsulated L. acidophilus KLDS 1.1003 & $20.31 \pm 1.01$ & $806.08 \pm 1.28^{\mathrm{e}}$ & $223.20 \pm 1.53^{\mathrm{a}}$ & $60.52 \pm 3.02^{a, b}$ \\
\hline Free L. acidophilus KLDS 1.1003 + lead & $20.77 \pm 1.03$ & $832.09 \pm 2.11^{b}$ & $193.07 \pm 2.23^{e}$ & $53.30 \pm 2.66^{c, d}$ \\
\hline MRS-based encapsulated L. acidophilus KLDS 1.1003 +lead & $20.93 \pm 1.04$ & $837.26 \pm 3.23^{\mathrm{a}}$ & $204.21 \pm 1.04^{\mathrm{c}}$ & $54.87 \pm 2.74^{\mathrm{C}}$ \\
\hline
\end{tabular}

Note: Data are expressed as mean \pm standard deviation.

According to the Tukey means post comparison test, different letters within different rows designate the significant difference.

$2.03 \mathrm{U} / \mathrm{mgprot})$. SOD and GSH were increased, whereas GSH-Px and MDA levels were significantly decreased $(p<0.05)$. As a whole, both the microencapsulated and free forms of KLDS 1.1003 imparted substantially protective properties against the chronic toxicity of $\mathrm{Pb}$ and helped in restoring and enhancing the antioxidant capacity $(p<0.05)$. Similarly, the variations in the levels of these parameters were protected significantly in the oral introduction of co-treatment with free and MRS encapsulated KLDS $1.1003+$ lead groups. In the same manner, the MDA and
GSH-Px levels were increased in kidneys after chronic exposure to $\mathrm{Pb}$ while the activities of SOD, GSH, and CAT enzymes were improved considerably. Marker enzymes, i.e., AST and ALT activities in the mice serum, have been presented in Figure 7.

\section{Histopathological Evaluation}

Histopathological studies showed that the mice tissues were severely harmed after chronic $\mathrm{Pb}$ exposure. The representative micrographs of the liver and kidney tissue samples of all groups 
TABLE 5|Effects of free and MRS-based encapsulated L. acidophilus 1.1003 on oxidative stress induced by chronic Pb exposure, differences of antioxidant capability in the kidney and liver.

\begin{tabular}{|c|c|c|c|c|c|}
\hline $\begin{array}{l}\text { Group } \\
\text { Liver }\end{array}$ & $\begin{array}{l}\text { SOD (U/ } \\
\text { mgprot) }\end{array}$ & $\begin{array}{c}\text { MDA (nmol/ } \\
\text { gprot) }\end{array}$ & $\begin{array}{l}\text { GSH (umol/ } \\
\text { mgprot) }\end{array}$ & $\begin{array}{l}\text { GSH-PX (U/ } \\
\text { mgprot) }\end{array}$ & CAT (U/mgprot) \\
\hline $\mathrm{C}+\mathrm{ve}$ & $45.52 \pm 0.62^{c}$ & $0.41 \pm 0.01^{\dagger}$ & $4.47 \pm 0.11^{\mathrm{a}}$ & $86.64 \pm 2.41^{\mathrm{a}}$ & $318.42 \pm 0.38^{\mathrm{a}}$ \\
\hline $\mathrm{C}-\mathrm{ve}$ & $32.35 \pm 0.06^{f}$ & $0.52 \pm 0.03^{a}$ & $1.33 \pm 0.13^{f}$ & $46.15 \pm 2.32^{f}$ & $111.18 \pm 1.01^{f}$ \\
\hline Free L. acidophilus KLDS 1.1003 & $46.66 \pm 0.38^{b}$ & $0.45 \pm 0.03^{e}$ & $3.36 \pm 0.53^{d}$ & $74.25 \pm 1.56^{\mathrm{c}}$ & $173.52 \pm 0.29^{d}$ \\
\hline Free L. acidophilus KLDS $1.1003+$ lead & $34.12 \pm 0.04^{e}$ & $0.47 \pm 0.01^{d}$ & $2.42 \pm 0.09^{e}$ & $53.48 \pm 1.59^{e}$ & $168.12 \pm 0.21^{e}$ \\
\hline MRS-based encapsulated L. acidophilus KLDS 1.1003 & $46.76 \pm 0.07^{a}$ & $0.46 \pm 0.01^{\mathrm{c}}$ & $3.75 \pm 0.10^{b}$ & $76.41 \pm 0.36^{b}$ & $223.89 \pm 1.41^{b}$ \\
\hline MRS-based encapsulated L. acidophilus KLDS 1.1003 & $35.19 \pm 0.01^{d}$ & $0.51 \pm 0.02^{b}$ & $3.61 \pm 0.07^{c}$ & $63.72 \pm 1.88^{d}$ & $176.62 \pm 0.40^{c}$ \\
\hline
\end{tabular}

+lead

\section{Kidney}

$\mathrm{C}+\mathrm{ve}$

$\begin{array}{lll}36.96 \pm 0.22^{\mathrm{c}} & 0.85 \pm 0.06^{\mathrm{b}} & 3.38 \pm 0.07^{\mathrm{b}} \\ 29.44 \pm 0.23^{f} & 1.16 \pm 0.03^{\mathrm{a}} & 1.47 \pm 0.21^{f} \\ 35.22 \pm 0.09^{\mathrm{d}} & 0.73 \pm 0.02^{\mathrm{e}} & 3.57 \pm 0.05^{\mathrm{a}} \\ 34.24 \pm 0.06^{\mathrm{e}} & 0.84 \pm 0.02^{\mathrm{c}} & 2.65 \pm 0.13^{\mathrm{d}} \\ 38.69 \pm 0.15^{\mathrm{a}} & 0.70 \pm 0.01^{\mathrm{f}} & 2.88 \pm 0.08^{\mathrm{c}} \\ 37.70 \pm 0.07^{\mathrm{b}} & 0.80 \pm 0.03^{\mathrm{d}} & 2.37 \pm 0.11^{\mathrm{e}}\end{array}$

$63.19 \pm 2.69^{b}$

$76.89 \pm 0.12^{\mathrm{a}}$

C -ve

Free L. acidophilus KLDS 1.1003

Free L. acidophilus KLDS 1.1003 + lead

MRS-based encapsulated L. acidophilus KLDS 1.1003

$37.70 \pm 0.07^{b}$

$0.80 \pm 0.03^{d}$

$2.37 \pm 0.11^{\mathrm{e}}$

$85.71 \pm 2.41^{\mathrm{a}}$

$49.53 \pm 2.61^{\mathrm{e}}$

$55.99 \pm 0.21^{f}$

$65.15 \pm 0.14^{\mathrm{b}}$

$59.01 \pm 0.44^{\mathrm{C}}$

$49.57 \pm 1.83^{\mathrm{e}}$

$58.83 \pm 0.20^{d}$

MRS-based encapsulated L. acidophilus KLDS 1.1003

+lead

$54.15 \pm 1.92^{d}$

$62.33+0.51^{\mathrm{cd}}$

$63.08 \pm 0.62^{\mathrm{c}}$

Note: Data are expressed as mean \pm standard deviation

According to the Tukey means post comparison test, different letters within different rows designate the significant difference.

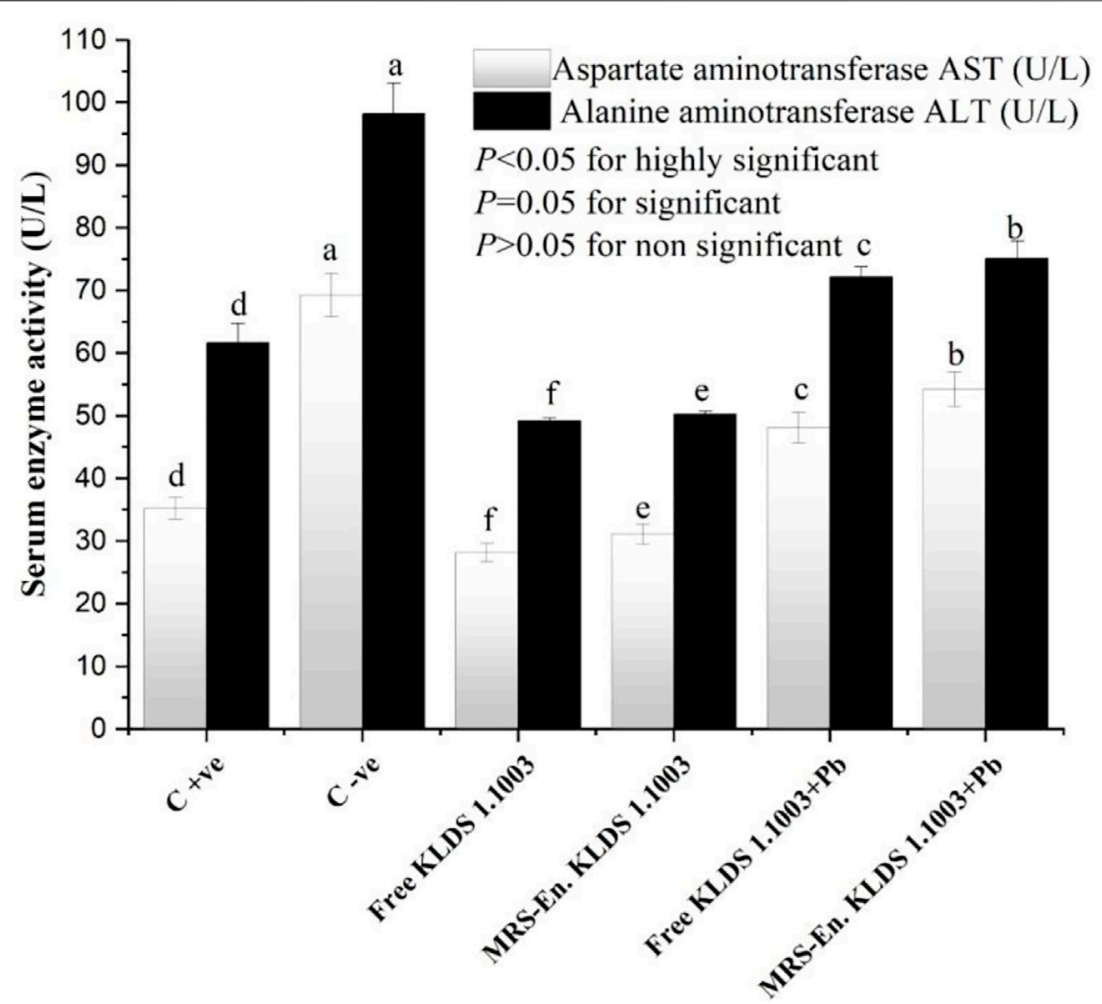

FIGURE 7 | Effects of free and MRS-based microencapsulated L. acidophilus KLDS 1.1003 on oxidative stress induced by chronic Pb exposure on the activity of marker enzymes such as aspartate aminotransferase (AST) and alanine aminotransferase (ALT) in the serum of mice. Values are mean \pm SD.

are displayed in Figures 8, 9. The hepatic damages were significantly relieved when treated with MRS microencapsulated and free KLDS 1.003 plus $\mathrm{Pb}$ (Figure 8). Histological alterations were produced in the liver after chronic exposure to $\mathrm{Pb}$. These alterations were comprised of cytoplasmic vacuolization, chromatin condensation, and injury of intact liver plates. Similarly, histopathological analyses of the liver in the $\mathrm{C}-\mathrm{ve}$ group Figure 8B displayed microvascular steatosis vacuolar 

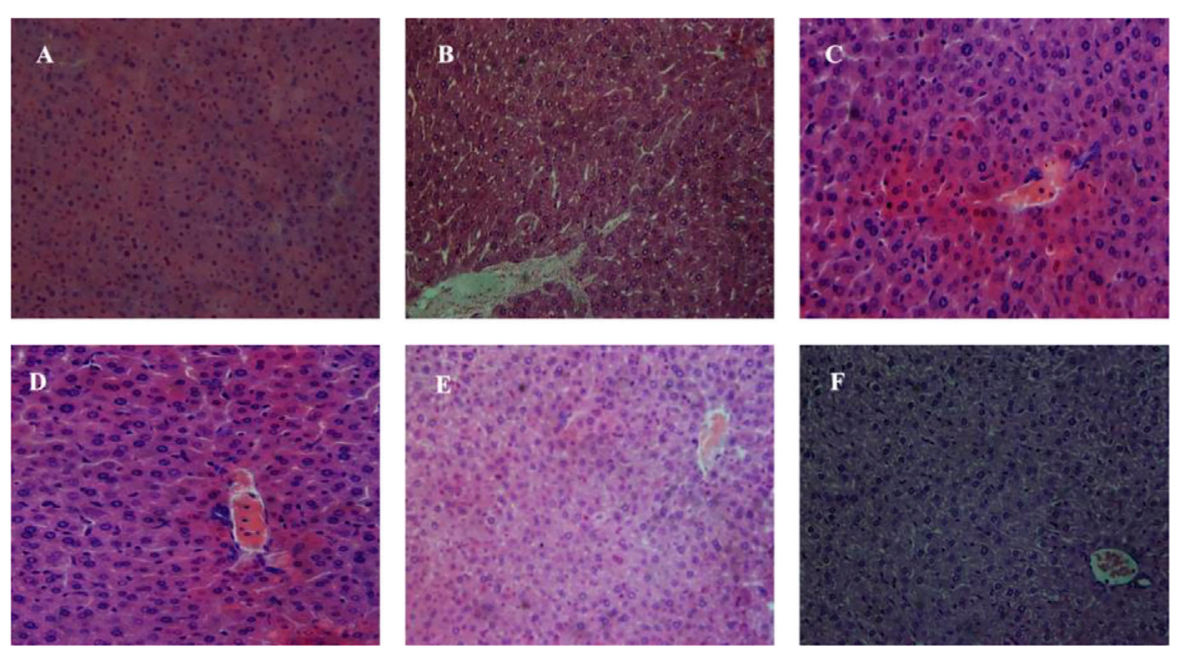

FIGURE 8 | Micrographs express the hepatic (liver) tissues of the mice hematoxylin-eosin (H\&E staining; magnifications $\times 400)$. (A) $C+v e$, (B) $C-v e$, (C) $L$. acidophilus KLDS 1.1003 only, (D) MRS-based encapsulated L. acidophilus KLDS 1.1003 only, (E) L. acidophilus KLDS 1.1003 plus lead, (F) MRS-based encapsulated L. acidophilus KLDS 1.1003 plus lead.
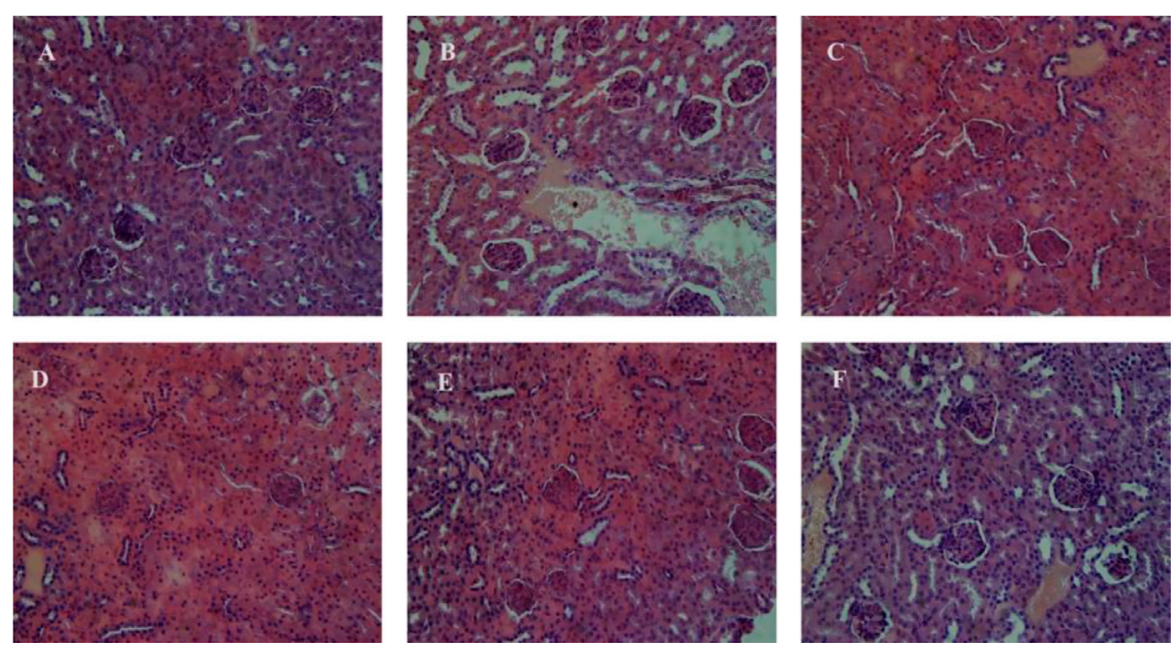

FIGURE 9 | Micrographs express the renal (kidney) tissues of the mice hematoxylin-eosin (H\&E staining; magnifications $\times 400)$. (A) C +ve, (B) C - ve, (C) $L$. acidophilus KLDS 1.1003 only, (D) MRS-based encapsulated L. acidophilus KLDS 1.1003 only, (E) L. acidophilus KLDS 1.1003 plus lead, (F) MRS-based encapsulated L. acidophilus KLDS 1.1003 plus lead.

degeneration and enlarged hepatocytes. Whereas the control Figure 8A did not show any obvious histopathological changes. At the same time, certain hepatocytes were observed, which swelled exceptionally. The protective effect against these swelling injuries is clear in groups with L. acidophilus KLDS 1.1003 only Figure 8C and MRS-based encapsulated L. acidophilus KLDS 1.1003 Figure 8D. But L. acidophilus KLDS 1.1003 plus lead Figure 8E and MRSbased encapsulated L. acidophilus KLDS 1.1003 plus lead Figure 8F showed better protective effects against the identical injuries in the liver.

Figure 9 shows the micrographs of kidney tissues, which clearly show the enlargement of glomeruli, cloudy swelling and necrosis of tubules in $\mathrm{C}$-ve treated groups, as compared to the control group. These renal damages were significantly relieved by free, and MRS encapsulated KLDS 1.1003+ lead treatments. Figure 9A shows the histomorphology of the kidney tissues of $\mathrm{C}+$ ve groups, which is apparently normal. It was noticed that the glomeruli were hyperemic (glomeruli with bigger volume) in $\mathrm{C}$-ve group, as these can be seen in Figure 9B. In addition, the swelling was also seen in the tubular epithelial cells of the renal tissues, and the missing glomeruli was also observed (Figures 9B,D,F). Some symptoms of the renal oxidative stress like swollen tubular epithelial cells (ST), glomerular hyperemic (GH), 
inflammatory cells (I), and granular degeneration (GD) were ameliorated (Figures 9C-F) in all treated groups comparing to the $\mathrm{C}$-ve group (Figure 9B).

No significant variations or differences were found in the hepatic and renal morphology of the free and MRS-based microencapsulated KLDS 1.003 treated groups after comparing with that of the $\mathrm{C}+\mathrm{ve}$ group.

\section{DISCUSSION}

Lead $(\mathrm{Pb})$ is a heavy metal pollutant that has no constructive biological role in the body, and it is a pestilent pollutant having ubiquitous existence in the environment. It can harm the host by inducing oxidative stress. Several research reports evidentially reported that lactic acid bacteria have the capability to sequester $\mathrm{Pb}$ metal ions as well as cope with the oxidative stress induced by its acute and chronic toxicity (Zhai et al., 2013, 2014; Li B. et al., 2017; Muhammad et al., 2018). Several properties should be taken into consideration during the screening process of specific $\mathrm{LAB}$ strains tackling $\mathrm{Pb}$ toxicity. The first and foremost criterion is the ability of LAB strains to exhibit higher $\mathrm{Pb}$ binding capability, which facilitates these strains to bind $\mathrm{Pb}$ before the host gets it through intestinal absorption. Secondly, these LAB strains should avoid toxicity by showing resistance to $\mathrm{Pb}$ ions and averting their noxiousness (Zhai et al., 2015; Allam et al., 2018).

Similarly, the higher viability of screened strains in highly concentrated bile and stomach acids is pivotally important to remove $\mathrm{Pb}$ from the gastrointestinal (San Keskin et al., 2018). As far as the present study is concerned, among the six tested $L$. acidophilus KLDS strains, a remarkably best tolerance and $\mathrm{Pb}$ binding aptitude have been shown by L. acidophilus KLDS1.1003 (Table 2). In addition, the $\mathrm{Pb}$ biosorption mechanism of this strain was also investigated. Moreover, maize-resistant starchbased microencapsulated $L$. acidophilus KLDS1.1003 not only showed significant resistance against the simulated gastrointestinal conditions, but also improved the $\mathrm{Pb}$ binding properties too (Figure 2). Considering these properties, $L$. acidophilus KLDS 1.1003 was selected as a free and microencapsulated potential LAB strain to study the in vivo assays further.

Different biosorption mechanisms to sequester heavy metals have been proposed depending upon the differences in the structure of bacterial species. These mechanisms include chelation and micro precipitation, complexation, ion exchange, and adsorption (Monachese et al., 2012). The contents like proteins, polysaccharides, teichoic acids, and peptidoglycans are present in the cell walls of gram-positive bacteria (Passot et al., 2015). The bacterial wall contents contain negatively charged functional groups, which act as the primary sites of metal ion sorption on the bacterial surfaces (Mishra et al., 2013; Yadav et al., 2014). The phosphate and carboxyl groups present in peptidoglycans and teichoic acid contents of the bacterial cell surface are the potential metal ion binding sites (Kazy et al., 2009). As it is obvious in the given SEM micrographs (Figure 3) that there is an even localization of the added $\mathrm{Pb}$ metal ion on the cell surface of bacteria, which confirms the theory as mentioned above. In previous research, a similar passive physicochemical phenomenon of heavy metal binding has been reported in $L$. bulgaricus (Li B. et al., 2017) and L. mesenteroides (Yi et al., 2017), explaining the $\mathrm{Pb}$ adsorption mechanism.

In our study, free and microencapsulated L. acidophilus were used as biosorbents. The chemical modification and surface characterization of these biosorbents due to the biosorption of metal ions were examined by the FTIR analysis. The involvement and identification of functional groups of free and microencapsulated bacterial biomass during the biosorption process was observed by this analysis. The highest observed spectral differences in the appearance of the spectrum are shown in Figure 4. Due to the presence of a large number of peaks, the FTIR spectra of free and microencapsulated $L$. acidophilus after biosorption indicated a complex nature of the biomass. The difference of biosorption was witnessed in the starch-based encapsulated and free bacterial biomass due to the increase or decrease in peak intensities, appearance of new peaks and shifting of the spectral bands. The functional groups are present in the structure of macromolecules like lipids, proteins, and polysaccharides.

Additionally, the bacterial cell wall offers many functional binding sites, such as sulfonates or phosphates, amines, carboxyl, and hydroxyl groups as well as, the shifting and broadening of the peaks were detected due to the interaction of metal ions with starch as compared to free bacterial biomass of the studied strains. The speculation that the carboxyl, hydroxyl, amino, amide, and phosphoryl functional groups of biological macromolecules have the ability to bind $\mathrm{Pb}$ ions through electrostatic attraction (physical adsorption), complexation, and ion exchange. Similarly, biopolymers like polysaccharides, teichoic acid, S-layer proteins, and fatty acids follow the mentioned mechanism for sequestering the $\mathrm{Pb}$ ions. These findings are consistently supported by the previous statements that the amide, hydroxyl, and carboxyl functional groups played a key role in uptaking the $\mathrm{Pb}$ (Afraz et al., 2020; Massoud et al., 2020).

Ren et al. also conducted a study related to the biosorption of $\mathrm{Pb}$ by using the Bacillus sp. PZ-1, and it supports the findings of our present research work (Ren et al., 2015). Moreover, the glucose pyranose rings showed skeletal mode vibrations due to which the complex vibrational modes of starches were shown at low wavenumbers (below $900 \mathrm{~cm}^{-1}$ ) (Soto et al., 2015, 2016). In addition, the active involvement of various carboxylic, hydroxyl, carbonyl, amine, and phosphate functional groups was also observed in starch-based microencapsulated biomass to sequester the metal ions of $\mathrm{Pb}$ (Bueno et al., 2008; Ma et al., 2015; Mohapatra et al., 2019).

In order to imitate the chronic or prolonged lead $(\mathrm{Pb})$ contact, it was orally supplied in drinking water. The concentration of $\mathrm{Pb}$ was taken as $100 \mathrm{mg} / \mathrm{L}$ to demonstrate the normal human and animal pertinent $\mathrm{Pb}$ ecological exposure in contaminated zones. This concentration was chosen, conferring the human and animal levels of $\mathrm{Pb}$ ingestion and body weight intensities (Fan et al., 2008). Herewith, we have investigated that microencapsulated $L$. acidophilus KLDS 1.1003 developed a superior capability to chelate $\mathrm{Pb}$. The enhancement in capability might be due to the 
maize-resistant starch, which provided substantial protection to bacteria against in vivo lead toxicity and also helped in the chelation of $\mathrm{Pb}$ ions, resulting in an ultimate decrease in lead concentrations in blood as well as in tissues (Figure 6.)

Similarly, KLDS 1.1003 also prohibited variations in the levels and activities of GSH, GSH-Px, MDA, and SOD in blood and tissues supporting antioxidant systems against induced oxidative stress. Our observations revealed that the free and microencapsulate L. acidophilus KLDS 1.1003 had affected the lead toxicity mechanism quite significantly by providing relief against lead-induced chronic toxicity. Lipid peroxidation and oxidative stress processes are accelerated as the MDA levels are increased, which resultantly disturb the SOD, DSH-Px, and GSH enzyme activities and eventually influence the antioxidant defense system of the body (Li B. et al., 2017; Muhammad et al., 2018).

Tian et al. and Muhammad et al. investigated the role of $L$. plantarum CCFM8661 on supporting antioxidant mechanisms by improving the enzymatic activity, plummeting lead concentrations in blood and tissues and, appeasing oxidative stress (Tian et al., 2015; Muhammad et al., 2018; Kinoshita et al., 2020). Li B. et al. (2017) also publicized that $L$. bulgaricus decreased the $\mathrm{Pb}$-induced oxidative stress and played a protective role by facilitating the increased levels of antioxidants like T-SOD, GSH-Px, and GSH and the reduction of MDA and lipid peroxide levels in the liver and kidneys. Mitochondrial dysfunction and energy metabolism impairment are lured by the GSH reduction (Pereira and Oliveira, 2000; Patel et al., 2017). It has also been observed that lactobacilli have a quicker and steadier biosorption ability to sequester lead in vitro with minimum chances of smooth desorption (Schut et al., 2011; Lin et al., 2019).

Furthermore, the loss of $\mathrm{Fe}, \mathrm{Zn}, \mathrm{Ca}$, and $\mathrm{Mg}$ (crucially essential) metals from the mice tissues was not done by the KLDS 1.1003 itself did (Table 4). Even a certain increase was observed in several vital elements, e.g., calcium (Ca) in the liver and iron (Fe) in the kidneys. Our study results indicated that the MRS-based microencapsulated KLDS 1.1003 therapy group contained a better potential to bind and defecate higher quantities of $\mathrm{Pb}$ from the animal body than free KLDS 1.003 groups. Some other lactobacilli also showed the corresponding observations by confining the heavy metal's absorption within the intestine of the mice and then excreting them through feces (Jomova and Valko, 2011; Zhai et al., 2013, 2014). Huang et al. (2011;2015) and Liu et al. (2018) also investigated and concluded that the structure of modified starches has the potential to confiscate $\mathrm{Pb}^{2+}$ (lead) and $\mathrm{Hg}^{2+}$ (mercury) ions (Huang et al., 2011, 2015; Liu et al., 2018). Usually, the prominent respective adsorption capabilities of modified starches are 123.2 and $131.2 \mathrm{mg} / \mathrm{g}$ for $\mathrm{Pb}^{2+}$ and $\mathrm{Hg}^{2+}$. In addition, San Keskin et al. (2018) also reported higher efficiencies $(70 \pm 0.2,58 \pm 1.4$ and $82 \pm 0.8 \%$ ) to remove $\mathrm{Ni}$ and $\mathrm{Cr}$ heavy metal ions from $30 \mathrm{mg} \mathrm{L}^{-1}$ concentrated solutions by using the Lysinibacillus sp. microencapsulated with cyclodextrin fiber (San Keskin et al., 2018).

According to several studies, there has been a possible relation between oxidative stress and disrupted homeostasis by heavy metal ions (Odewabi and Ekor, 2017; Galaris et al., 2019; Yang et al., 2020). Changes in AST/ALT levels are frequently used to study liver pathology as AST/ALT is an imperatively vital biochemical indicator (Soliman et al., 2020; Aljobaily et al., 2021). The cell plasma of the liver is the main existing place of ALT. As the liver-cell membrane permeability changes, the ALT levels are increased in the blood with the lower damage of the liver cells. In contrast, the escalation of AST levels in the blood indicate severely damaged liver cells, as can be seen in the data presented in Figure 7. Keeping in view of the above discussion, it could be conclusively stated that the higher the AST/ALT ratios, the worst damage will be experienced to liver cells. According to several recently conducted studies, it could be concluded that the LAB ( $L$. bulgaricus and L. plantarum) treatments can potentially intensify the ALT and AST levels. While, if the LAB's are microencapsulated with modified starches like MRS then, the heavy metal absorbing ability of probiotic lactic acid bacteria can be increased (Li B. et al., 2017; Liu et al., 2018; Muhammad et al., 2018; San Keskin et al., 2018; Mohammadian et al., 2020). And these prebiotic/probiotic combinations can be taken as a natural biosorbing remedy to tackle the induced oxidative stress by chronic toxicity of $\mathrm{Pb}$ and other toxic heavy metals.

\section{CONCLUSION}

L. acidophilus KLDS1.1003 showed great in vitro and in vivo capacities with respect to the tolerance and biosorption of $\mathrm{Pb}$ and relieved against induced oxidative stress. The main functional groups, i.e., hydroxyl, carboxyl, phosphoryl, amino and, amide groups in bacterial cell walls and polysaccharide structure, played a key and efficient role in the complexation and adsorption $\mathrm{Pb}$ ions. Free and MRS-based microencapsulated KLDS 1.0344 not only improved the antioxidant index and inhibited changes in blood and serum enzyme concentrations and also relieved the $\mathrm{Pb}$-induced renal and hepatic pathological damages. L. acidophilus KLDS1.1003 in both forms facilitated the detoxification process of $\mathrm{Pb}$ in vivo. It conserved the antioxidant defense system of the $\mathrm{Pb}$ exposed animal by maintaining the activities and concentrations of GSH, GPx, SOD, CAT, and MDA in renal and hepatic tissues and ALT/AST ratios in blood and serum. Conclusively, a symbiotic combination of prebiotics/probiotics in $\mathrm{Pb}$ binding, bioquenching, damage repairing capacities of orally administered MRS microencapsulated and free L. acidophilus KLDS 1.1003 bacteria against inflammation and induced oxidative stress due to chronic exposure of $\mathrm{Pb}$ make them ideal and natural remedying candidates tackling heavy metal lethality.

\section{DATA AVAILABILITY STATEMENT}

The raw data supporting the conclusions of this article will be made available by the authors, without undue reservation. 


\section{ETHICS STATEMENT}

The animal study was reviewed and approved by the Ethics Committee of Guangdong Academy of Agricultural Sciences.

\section{AUTHOR CONTRIBUTIONS}

ZM: conceptualization, methodology and experiments, formal analyses, writing-original draft preparation. RR: methodology, formal analyses, writing-original draft preparation. RZ, DZ, MG, and DL: writing-review and editing. MZ: supervision and funding

\section{REFERENCES}

Afraz, V., Younesi, H., Bolandi, M., and Hadiani, M. R. (2020). Optimization of lead and Cadmium Biosorption by Lactobacillus Acidophilus Using Response Surface Methodology. Biocatal. Agric. Biotechnol. 29, 101828. doi:10.1016/ j.bcab.2020.101828

Ali, H., and Khan, E. (2019). Trophic Transfer, Bioaccumulation, and Biomagnification of Non-essential Hazardous Heavy Metals and Metalloids in Food Chains/webs-Concepts and Implications for Wildlife and Human Health. Hum. Ecol. Risk Assess. Int. J. 25, 1353-1376. doi:10.1080/ 10807039.2018.1469398

Aljobaily, N., Viereckl, M. J., Hydock, D. S., Aljobaily, H., Wu, T.-Y., Busekrus, R., et al. (2021). Creatine Alleviates Doxorubicin-Induced Liver Damage by Inhibiting Liver Fibrosis, Inflammation, Oxidative Stress, and Cellular Senescence. Nutrients 13, 41. doi:10.3390/nu13010041

Al-Wabel, N. A., Mousa, H. M., Omer, O. H., and Abdel-Salam, A. M. (2007). Biological Evaluation of Synbiotic Fermented Milk against lead Acetate Contamination in Rats. J. Food Agric. Environ. 5, 169-172.

Baharuddin, N. H., Sulaiman, N. M. N., Aroua, M. K., Nawawi, M. G. M., Kassim, M. A., Othman, M. R., and Dahlan, I. (2019). "Starch as Novel Water Soluble Biopolymer in Removal Mixtures Heavy Metal Ions via Polymer Enhanced Ultrafiltration," in AIP Conference Proceedings, Penang, Malaysia, December 11-13, 2018. doi:10.1063/1.5117134

Bayer, G. (2015). Martindale: The Complete Drug Reference. 38th Ed. Aust. Prescr. 38, 59. doi:10.18773/austprescr.2015.023

Beni, A. A., and Esmaeili, A. (2020). Biosorption, an Efficient Method for Removing Heavy Metals from Industrial Effluents: A Review. Environ. Technol. Innovation 17, 100503. doi:10.1016/j.eti.2019.100503

Bhat, M. A., Chisti, H., and Shah, S. A. (2015). Removal of Heavy Metal Ions from Water by Cross-Linked Potato Di-starch Phosphate Polymer. Sep. Sci. Technol. 50, 1741-1747. doi:10.1080/01496395.2014.978469

Bhattacharya, S. (2019). Probiotics against Alleviation of lead Toxicity: Recent Advances. Interdiscip. Toxicol. 12, 89-92. doi:10.2478/intox-2019-0010

Boskabady, M., Marefati, N., Farkhondeh, T., Shakeri, F., Farshbaf, A., and Boskabady, M. H. (2018). The Effect of Environmental lead Exposure on Human Health and the Contribution of Inflammatory Mechanisms, a Review. Environ. Int. 120, 404-420. doi:10.1016/j.envint.2018.08.013

Bueno, B. Y. M., Torem, M. L., Molina, F., and de Mesquita, L. M. S. (2008). Biosorption of Lead(II), Chromium(III) and Copper(II) by R. Opacus: Equilibrium and Kinetic Studies. Minerals Eng. 21, 65-75. doi:10.1016/ j.mineng.2007.08.013

Chakravarty, R., and Banerjee, P. C. (2012). Mechanism of Cadmium Binding on the Cell wall of an Acidophilic Bacterium. Bioresour. Technol. 108, 176-183. doi:10.1016/j.biortech.2011.12.100

Chedea, V. S., Palade, L. M., Pelmus, R. S., Dragomir, C., and Taranu, I. (2019). Red Grape Pomace Rich in Polyphenols Diet Increases the Antioxidant Status in Key Organs-Kidneys, Liver, and Spleen of Piglets. Animals 9, 149, 2019. Animals 9. doi:10.3390/ani9040149

Dobrakowski, M., Pawlas, N., Hudziec, E., Kozłowska, A., Mikołajczyk, A., Birkner, E., et al. (2016). Glutathione, Glutathione-Related Enzymes, and Oxidative acquisition. All authors have read and approved the final manuscript.

\section{FUNDING}

This study was supported by the National Key Research Project of China (2017YFC1601002), the Guangdong special support program (2019BT02N112), the special fund for scientific innovation strategy-construction of high-level Academy of Agriculture Science (R2020PY-JG011, 202108TD) and, the Guangdong Academy of Agricultural Sciences Foundation of the Dean Project (BZ202003).

Stress in Individuals with Subacute Occupational Exposure to lead. Environ. Toxicol. Pharmacol. 45, 235-240. doi:10.1016/j.etap.2016.06.008

Duan, H., Yu, L., Tian, F., Zhai, Q., Fan, L., and Chen, W. (2020). Gut Microbiota: A Target for Heavy Metal Toxicity and a Probiotic Protective Strategy. Sci. Total Environ. 742, 140429. doi:10.1016/j.scitotenv.2020.140429

Elsanhoty, R. M., Al-Turki, I. A., and Ramadan, M. F. (2016). Application of Lactic Acid Bacteria in Removing Heavy Metals and Aflatoxin B1 from Contaminated Water. Water Sci. Technol. 74, 625-638. doi:10.2166/wst.2016.255

Fan, T., Liu, Y., Feng, B., Zeng, G., Yang, C., Zhou, M., et al. (2008). Biosorption of Cadmium(II), Zinc(II) and Lead(II) by Penicillium simplicissimum: Isotherms, Kinetics and Thermodynamics. J. Hazard. Mater. 160, 655-661. doi:10.1016/ j.jhazmat.2008.03.038

Feng, P., Ye, Z., Han, H., Ling, Z., Zhou, T., Zhao, S., et al. (2020). Tibet Plateau Probiotic Mitigates Chromate Toxicity in Mice by Alleviating Oxidative Stress in Gut Microbiota. Commun. Biol. 3, 242. doi:10.1038/s42003-020-0968-3

G Allam, N., M Ali, E. M., Shabanna, S., and Abd-Elrahman, E. (2018). Protective Efficacy of Streptococcus Thermophilus against Acute Cadmium Toxicity in Mice. Iran. J. Pharm. Res. 17, 695-707. doi:10.22037/ijpr.2018.2194

Galaris, D., Barbouti, A., and Pantopoulos, K. (2019). Iron Homeostasis and Oxidative Stress: An Intimate Relationship. Biochim. Biophys. Acta (Bba) - Mol. Cel Res. 1866, 118535. doi:10.1016/j.bbamcr.2019.118535

Gomiero, T. (2018). Food Quality Assessment in Organic vs. Conventional Agricultural Produce: Findings and Issues. Appl. Soil Ecol. 123, 714-728. doi:10.1016/j.apsoil.2017.10.014

García-Rodríguez, M. d. C., Nicolás-Méndez, T., Ortiz-Muñiz, A. R., MendozaNúñez, V. M., and del, C. (2020). The Role of Resveratrol on Heavy MetalInduced Oxidative Stress. Nutr. Hosp. 37, 374-383. doi:10.20960/nh.02846

Gupta, K., Chatterjee, C., and Gupta, B. (2012). Isolation and Characterization of Heavy Metal Tolerant Gram-Positive Bacteria with Bioremedial Properties from Municipal Waste Rich Soil of Kestopur Canal (Kolkata), West Bengal, India. Biologia 67, 827-836. doi:10.2478/s11756-012-0099-5

Hasanein, P., and Emamjomeh, A. (2019). "Beneficial Effects of Natural Compounds on Heavy Metal-Induced Hepatotoxicity," in Dietary Interventions in Liver Disease: Foods, Nutrients, and Dietary Supplements (London: Academic Press, Elsevier), 345-355. doi:10.1016/B978-0-12814466-4.00028-8

Hoque, M. I. U., Yamauchi, Y., Naidu, R., Holze, R., Saidur, R., Qu, Q., et al. (2019). A Facile Synthesis of Hematite Nanorods from Rice Starch and Their Application to $\mathrm{Pb}(\mathrm{II})$ Ions Removal. ChemistrySelect 4, 3730-3736. doi:10.1002/slct.201802462

Huang, L., Xiao, C., and Chen, B. (2011). A Novel Starch-Based Adsorbent for Removing Toxic $\mathrm{Hg}(\mathrm{II})$ and $\mathrm{Pb}(\mathrm{II})$ Ions from Aqueous Solution. J. Hazard. Mater. 192, 832-836. doi:10.1016/j.jhazmat.2011.05.094

Huang, D.-L., Wang, R.-Z., Liu, Y.-G., Zeng, G.-M., Lai, C., Xu, P., et al. (2015). Application of Molecularly Imprinted Polymers in Wastewater Treatment: a Review. Environ. Sci. Pollut. Res. 22, 963-977. doi:10.1007/s11356-014-3599-8

Jafarpour, D., Shekarforoush, S. S., Ghaisari, H. R., Nazifi, S., Sajedianfard, J., and Eskandari, M. H. (2017). Protective Effects of Synbiotic Diets of Bacillus Coagulans, Lactobacillus Plantarum and Inulin against Acute Cadmium Toxicity in Rats. BMC Complement. Altern. Med. 17, 291. doi:10.1186/ s12906-017-1803-3 
Jomova, K., and Valko, M. (2011). Advances in Metal-Induced Oxidative Stress and Human Disease. Toxicology 283, 65-87. doi:10.1016/j.tox.2011.03.001

Kabeer, A., Muhammad Mailafiya, M., Danmaigoro, A., Abdul Rahim, E., and Bu Bakar, M. Z. A. (2019). Therapeutic Potential of Curcumin against lead-induced Toxicity: A Review. Biomed. Res. Ther. 6, 3053-3066. doi:10.15419/ bmrat.v6i3.528

Kang, Y., Pan, W., Liang, S., Li, N., Zeng, L., Zhang, Q., et al. (2016). Assessment of Relative Bioavailability of Heavy Metals in Soil Using In Vivo Mouse Model and its Implication for Risk Assessment Compared with Bioaccessibility Using In Vitro Assay. Environ. Geochem. Health 38, 1183-1191. doi:10.1007/s10653015-9782-0

Kazy, S. K., D'Souza, S. F., and Sar, P. (2009). Uranium and Thorium Sequestration by a Pseudomonas sp.: Mechanism and Chemical Characterization. J. Hazard. Mater. 163, 65-72. doi:10.1016/j.jhazmat.2008.06.076

Kenny, C. R., Lucey, B., and Furey, A. (2020). Adverse Human Health Effects and Regulation of Metal Contaminants in Terrestrial Plant-Derived Food and Phytopharmaceuticals. Spices Med. Plants, 321-375. doi:10.1002/ 9781119036685.ch12

Ketsela, G., Animen, Z., and Talema, A. (2020). Adsorption of Lead (II), Cobalt (II) and Iron (II) from Aqueous Solution by Activated Carbon Prepared from White Lupine (GIBITO) HUSK. J. Thermodyn. Catal. 11, 1-8. doi:10.4172/21577544.20.11.2.203

Khayyun, T. S., and Mseer, A. H. (2019). Comparison of the Experimental Results with the Langmuir and Freundlich Models for Copper Removal on limestone Adsorbent. Appl. Water Sci. 9, 1-8. doi:10.1007/s13201-019-1061-2

Kinoshita, H., Jumonji, M., Yasuda, S., and Igoshi, K. (2020). Protection of Human Intestinal Epithelial Cells from Oxidative Stress Caused by Mercury Using Lactic Acid Bacteria. Biosci. Microbiota, Food Heal. 39, 183-187. doi:10.12938/ bmfh.2019-049

Kirn, B. S., and Lim, S. T. (1999). Removal of Heavy Metal Ions from Water by Cross-Linked Carboxymethyl Corn Starch. Carbohydr. Polym. 39, 217-223. doi:10.1016/S0144-8617(99)00011-9

Kumar, A., Kumar, A., M.M.S., C.-P., Chaturvedi, A. K., Shabnam, A. A., Subrahmanyam, G., et al. (2020). Lead Toxicity: Health Hazards, Influence on Food Chain, and Sustainable Remediation Approaches. Ijerph 17, 2179. doi:10.3390/ijerph17072179

Li, B., Jin, D., Yu, S., Etareri Evivie, S., Muhammad, Z., Huo, G., et al. (2017). In Vitro and In Vivo Evaluation of Lactobacillus Delbrueckii Subsp. Bulgaricus KLDS1.0207 for the Alleviative Effect on Lead Toxicity. Nutrients 9, 845. doi:10.3390/nu9080845

Li, L., Xu, G., Shao, H., Zhang, Z.-H., Pan, X.-F., and Li, J.-Y. (2017c). Analysis of Blood Concentrations of Zinc, Germanium, and lead and Relevant Environmental Factors in a Population Sample from Shandong Province, China. Ijerph 14, 227. doi:10.3390/ijerph14030227

Lin, D., Cao, H., Zhong, Y., Huang, Y., Zou, J., He, Q., et al. (2019). Screening and Identification of Lactic Acid Bacteria from Ya'an Pickle Water to Effectively Remove Pb2+. AMB Expr. 9. doi:10.1186/s13568-018-0724-y

Liu, Q., Li, F., Lu, H., Li, M., Liu, J., Zhang, S., et al. (2018). Enhanced Dispersion Stability and Heavy Metal Ion Adsorption Capability of Oxidized Starch Nanoparticles. Food Chem. 242, 256-263. doi:10.1016/j.foodchem.2017.09.071

Liu, X., Chen, Q., Ali, N., Zhang, J., Wang, M., and Wang, Z. (2019). Single and Joint Oxidative Stress-Related Toxicity of Sediment-Associated Cadmium and lead on Bellamya Aeruginosa. Environ. Sci. Pollut. Res. 26, 24695-24706. doi:10.1007/s11356-019-05769-9

Ma, Y., Wang, P., Wang, C., Zhang, S. H., and Cheng, S. (2015). Isolation and Characterization of $\mathrm{Pb}$-Resistant Strains and the Removal of $\mathrm{Pb}(\mathrm{II})$. Fresenius Environ. Bull. 24, 1150-1157.

Maret, W. (2017). "1. The Bioinorganic Chemistry of Lead in the Context of its Toxicity," in Lead: Its Effects on Environment and Health (Berlin/Munich/ Boston, Germany: Walter de Gruyter GmbH), 1-20. doi:10.1515/ 9783110434330-001

Massoud, R., Khosravi-Darani, K., Sharifan, A., Asadi, G., and Zoghi, A. (2020). Lead and Cadmium Biosorption from Milk by Lactobacillus Acidophilus ATCC 4356. Food Sci. Nutr. 8, 5284-5291. doi:10.1002/fsn3.1825

Meucci, V., Battaglia, F., Marchetti, V., Gori, E., and Intorre, L. (2020). Rapid and Simultaneous Electrochemical Method to Measure Copper and lead in Canine Liver Biopsy. MethodsX 7, 101154. doi:10.1016/j.mex.2020.101154
Mishra, V., Balomajumder, C., and Agarwal, V. K. (2013). Dynamic, Mechanistic, and Thermodynamic Modeling of $\mathrm{Zn}(\mathrm{II})$ Ion Biosorption onto Zinc Sequestering BacteriumVMSDCM. Clean. Soil Air Water 41, 883-889. doi:10.1002/clen.201200532

Mohammadian, T., Dezfuly, Z. T., Motlagh, R. G., Jangaran-Nejad, A., Hosseini, S. S., Khaj, H., et al. (2020). Effect of Encapsulated Lactobacillus Bulgaricus on Innate Immune System and Hematological Parameters in Rainbow Trout (Oncorhynchus mykiss), Post-Administration of Pb. Probiotics Antimicro. Prot. 12, 375-388. doi:10.1007/s12602-019-09544-7

Mohapatra, R. K., Parhi, P. K., Pandey, S., Bindhani, B. K., Thatoi, H., and Panda, C. R. (2019). Active and Passive Biosorption of Pb(II)using Live and Dead Biomass of marine Bacterium Bacillus Xiamenensis PbRPSD202: Kinetics and Isotherm Studies. J. Environ. Manage. 247, 121-134. doi:10.1016/ j.jenvman.2019.06.073

Monachese, M., Burton, J. P., and Reid, G. (2012). Bioremediation and Tolerance of Humans to Heavy Metals through Microbial Processes: a Potential Role for Probiotics? Appl. Environ. Microbiol. 78, 6397-6404. doi:10.1128/AEM.01665-12

Muhammad, Z., Ramzan, R., Huo, G.-C., Tian, H., and Bian, X. (2017). Integration of Polysaccharide-Thermoprotectant Formulations for Microencapsulation of Lactobacillus Plantarum, Appraisal of Survivability and Physico-Biochemical Properties during Storage of spray Dried Powders. Food Hydrocolloids 66, 286-295. doi:10.1016/j.foodhyd.2016.11.040

Muhammad, Z., Ramzan, R., Zhang, S., Hu, H., Hameed, A., Bakry, A. M., et al. (2018). Comparative Assessment of the Bioremedial Potentials of Potato Resistant Starch-Based Microencapsulated and Nonencapsulated Lactobacillus Plantarum to Alleviate the Effects of Chronic lead Toxicity. Front. Microbiol. 9, 1306. doi:10.3389/fmicb.2018.01306

Muhammad, Z., Ramzan, R., Abdelazez, A., Amjad, A., Afzaal, M., Zhang, S., et al. (2019). Assessment of the Antimicrobial Potentiality and Functionality of Lactobacillus Plantarum Strains Isolated from the Conventional Inner Mongolian Fermented Cheese against Foodborne Pathogens. Pathogens 8, 71. doi:10.3390/pathogens8020071

Muhammad, Z., Ramzan, R., Zhang, R., and Zhang, M. (2021). Resistant StarchBased Edible Coating Composites for spray-dried Microencapsulation of Lactobacillus Acidophilus, Comparative Assessment of thermal protection, In Vitro Digestion and Physicochemical Characteristics. Coatings 11, 587. doi:10.3390/coatings11050587

Odewabi, A. O., and Ekor, M. (2017). Levels of Heavy and Essential Trace Metals and Their Correlation with Antioxidant and Health Status in Individuals Occupationally Exposed to Municipal Solid Wastes. Toxicol. Ind. Health 33, 431-442. doi:10.1177/0748233716669276

Ojekunle, O., Banwo, K., and Sanni, A. I. (2017). In Vitro and In Vivo Evaluation of Weissella Cibaria and Lactobacillus Plantarum for Their Protective Effect against Cadmium and lead Toxicities. Lett. Appl. Microbiol. 64, 379-385. doi:10.1111/lam.12731

Olawoyin, R., Schweitzer, L., Zhang, K., Okareh, O., and Slates, K. (2018). Index Analysis and Human Health Risk Model Application for Evaluating Ambient Air-Heavy Metal Contamination in Chemical Valley Sarnia. Ecotoxicol. Environ. Saf. 148, 72-81. doi:10.1016/j.ecoenv.2017.09.069

Passot, S., Gautier, J., Jamme, F., Cenard, S., Dumas, P., and Fonseca, F. (2015). Understanding the Cryotolerance of Lactic Acid Bacteria Using Combined Synchrotron Infrared and Fluorescence Microscopies. Analyst 140, 5920-5928. doi:10.1039/C5AN00654F

Patel, A., Sv, A., Shah, N., and Verma, D. K. (2017). Lactic Acid Bacteria as Metal Quenchers to Improve Food Safety and Quality. AgroLife 6, 146-154.

Pereira, C. F., and Oliveira, C. R. d. (2000). Oxidative Glutamate Toxicity Involves Mitochondrial Dysfunction and Perturbation of Intracellular $\mathrm{Ca} 2+$ Homeostasis. Neurosci. Res. 37, 227-236. doi:10.1016/S0168-0102(00)00124-3

Priyan, V. V., Shahnaz, T., Kunnumakkara, A. B., Rana, V., Saravanan, M., and Narayanasamy, S. (2020). Antioxidant, Anti-inflammatory and Biosorption Properties of Starch Nanocrystals In Vitro Study: Cytotoxic and Phytotoxic Evaluation. J. Clust. Sci. 32, 1419-1430. doi:10.1007/s10876-020-01905-5

Ren, G., Jin, Y., Zhang, C., Gu, H., and Qu, J. (2015). Characteristics of Bacillus Sp. PZ-1 and its Biosorption to $\mathrm{Pb}(\mathrm{II})$. Ecotoxicol. Environ. Saf. 117, 141-148. doi:10.1016/j.ecoenv.2015.03.033

Rodríguez, J., and Mandalunis, P. M. (2018). A Review of Metal Exposure and its Effects on Bone Health. J. Toxicol. 2018, 1-11. doi:10.1155/2018/4854152 
San Keskin, N. O., Celebioglu, A., Sarioglu, O. F., Uyar, T., and Tekinay, T. (2018). Encapsulation of Living Bacteria in Electrospun Cyclodextrin Ultrathin Fibers for Bioremediation of Heavy Metals and Reactive Dye from Wastewater. Colloids Surf. B: Biointerf. 161, 169-176. doi:10.1016/j.colsurfb.2017.10.047

Schär-Zammaretti, P., and Ubbink, J. (2003). The Cell Wall of Lactic Acid Bacteria: Surface Constituents and Macromolecular Conformations. Biophys. J. 85, 4076-4092. doi:10.1016/S0006-3495(03)74820-6

Schut, S., Zauner, S., Hampel, G., König, H., and Claus, H. (2011). Biosorption of Copper by Wine-Relevant Lactobacilli. Int. J. Food Microbiol. 145, 126-131. doi:10.1016/j.ijfoodmicro.2010.11.039

Shaban, N. Z., Abd El-Kader, S. E., Mogahed, F. A. K., El-Kersh, M. A. L., and Habashy, N. H. (2021). Synergistic Protective Effect of Beta Vulgaris with Meso2,3-Dimercaptosuccinic Acid against lead-induced Neurotoxicity in Male Rats. Sci. Rep. 11, 252. doi:10.1038/s41598-020-80669-4

Singh Sankhla, M., Kumar, R., Sonone, S. S., and Jadhav, S. (2021). Water Contamination by Heavy Metals and Their Toxic Effect on Aquaculture and Human Health through Food Chain. Lett. Appl. Nano BioSci. 10, 2148-2166. researchgate.net. doi:10.33263/lianbs102.21482166

Soliman, M. M., Aldhahrani, A., Alkhedaide, A., Nassan, M. A., Althobaiti, F., and Mohamed, W. A. (2020). The Ameliorative Impacts of Moringa Oleifera Leaf Extract against Oxidative Stress and Methotrexate-Induced Hepato-Renal Dysfunction. Biomed. Pharmacother. 128, 110259. doi:10.1016/j.biopha.2020.110259

Soto, D., Urdaneta, J., Pernía, K., León, O., Muñoz-Bonilla, A., and FernándezGarcía, M. (2015). Heavy Metal (Cd2+, Ni2+, Pb2+and Ni2+) Adsorption in Aqueous Solutions by Oxidized Starches. Polym. Adv. Technol. 26, 147-152. doi:10.1002/pat.3439

Soto, D., Urdaneta, J., Pernía, K., León, O., Muñoz-Bonilla, A., and FernandezGarcía, M. (2016). Removal of Heavy Metal Ions in Water by Starch Esters. Starch - Stärke 68, 37-46. doi:10.1002/star.201500155

Specht, A. J., Lin, Y., Weisskopf, M., Yan, C., Hu, H., Xu, J., et al. (2016). XRFmeasured Bone lead $(\mathrm{Pb})$ as a Biomarker for $\mathrm{Pb}$ Exposure and Toxicity Among Children Diagnosed with Pb Poisoning. Biomarkers 21, 347-352. doi:10.3109/ 1354750X.2016.1139183

Sun, W., Cheng, K., Sun, K. Y., and Ma, X. (2021). Microbially Mediated Remediation of Contaminated Sediments by Heavy Metals: a Critical Review. Curr. Pollut. Rep. 7, 201-212. doi:10.1007/s40726-021-00175-7

Taylor, M. P., and Schniering, C. (2010). The Public Minimization of the Risks Associated with Environmental lead Exposure and Elevated Blood lead Levels in Children, Mount Isa, Queensland, Australia. Arch. Environ. Occup. Health 65, 45-48. doi:10.1080/19338240903338189

Tian, F., Xiao, Y., Li, X., Zhai, Q., Wang, G., Zhang, Q., et al. (2015). Protective Effects of Lactobacillus Plantarum CCFM8246 against Copper Toxicity in Mice. PLoS One 10, e0143318. doi:10.1371/journal.pone.0143318

Ubando, A. T., Africa, A. D. M., Maniquiz-Redillas, M. C., Culaba, A. B., Chen, W.H., and Chang, J.-S. (2021). Microalgal Biosorption of Heavy Metals: A Comprehensive Bibliometric Review. J. Hazard. Mater. 402, 123431. doi:10.1016/j.jhazmat.2020.123431

Ubbink, J., and Schär-Zammaretti, P. (2007). Colloidal Properties and Specific Interactions of Bacterial Surfaces. Curr. Opin. Colloid Interf. Sci. 12, 263-270. doi:10.1016/j.cocis.2007.08.004

Wang, Z.-M., Wagner, J., Ghosal, S., Bedi, G., and Wall, S. (2017). SEM/EDS and Optical Microscopy Analyses of Microplastics in Ocean Trawl and Fish Guts. Sci. Total Environ. 603-604, 616-626. doi:10.1016/j.scitotenv.2017.06.047

Wei, B., He, M., Cai, X., Hou, X., Wang, Y., Chen, J., et al. (2019). Vitamin E Succinate-Grafted-Chitosan/chitosan Oligosaccharide Mixed Micelles Loaded with C-DMSA for $\mathrm{Hg} 2+$ Detection and Detoxification in Rat Liver. Int. J. Nanomed. 14, 6917-6932. doi:10.2147/IJN.S213084
Wu, J., Zhou, Q., Huang, R., Wu, K., and Li, Z. (2021). Contrasting Impacts of Mobilisation and Immobilisation Amendments on Soil Health and Heavy Metal Transfer to Food Chain. Ecotoxicol. Environ. Saf. 209, 111836. doi:10.1016/j.ecoenv.2020.111836

Yadav, A., Mathur, R., Samim, M., Lomash, V., Kushwaha, P., Pathak, U., et al. (2014). Nanoencapsulation of DMSA Monoester for Better Therapeutic Efficacy of the Chelating Agent against Arsenic Toxicity. Nanomedicine 9, 465-481. doi:10.2217/nnm.13.17

Yang, J., Pan, X., Xu, Y., Li, Y., Xu, N., Huang, Z., et al. (2020). Agrobacterium Tumefaciens Ferritins Play an Important Role in Full Virulence through Regulating Iron Homeostasis and Oxidative Stress Survival. Mol. Plant Pathol. 21, 1167-1178. doi:10.1111/mpp.12969

Yi, Y.-J., Lim, J.-M., Gu, S., Lee, W.-K., Oh, E., Lee, S.-M., et al. (2017). Potential Use of Lactic Acid Bacteria Leuconostoc Mesenteroides as a Probiotic for the Removal of $\mathrm{Pb}(\mathrm{II})$ Toxicity. J. Microbiol. 55, 296-303. doi:10.1007/s12275017-6642-x

Yu, L., Zhai, Q., Yin, R., Li, P., Tian, F., Liu, X., et al. (2017). Lactobacillus Plantarum CCFM639 Alleviate Trace Element Imbalance-Related Oxidative Stress in Liver and Kidney of Chronic Aluminum Exposure Mice. Biol. Trace Elem. Res. 176, 342-349. doi:10.1007/s12011-016-0843-8

Zanjani, S. Y., Eskandari, M. R., Kamali, K., and Mohseni, M. (2017). The Effect of Probiotic Bacteria (Lactobacillus Acidophilus and Bifidobacterium Lactis) on the Accumulation of lead in Rat Brains. Environ. Sci. Pollut. Res. 24, 1700-1705. doi:10.1007/s11356-016-7946-9

Zhai, Q., Wang, G., Zhao, J., Liu, X., Tian, F., Zhang, H., et al. (2013). Protective Effects of Lactobacillus Plantarum Ccfm8610 against Acute Cadmium Toxicity in Mice. Appl. Environ. Microbiol. 79, 1508-1515. doi:10.1128/AEM.03417-12

Zhai, Q., Wang, G., Zhao, J., Liu, X., Narbad, A., Chen, Y. Q., et al. (2014). Protective Effects of Lactobacillus Plantarum CCFM8610 against Chronic Cadmium Toxicity in Mice Indicate Routes of protection besides Intestinal Sequestration. Appl. Environ. Microbiol. 80, 4063-4071. doi:10.1128/ AEM.00762-14

Zhai, Q., Yin, R., Yu, L., Wang, G., Tian, F., Yu, R., et al. (2015). Screening of Lactic Acid Bacteria with Potential Protective Effects against Cadmium Toxicity. Food Control 54, 23-30. doi:10.1016/j.foodcont.2015.01.037

Zhai, Q., Xiao, Y., Zhao, J., Tian, F., Zhang, H., Narbad, A., et al. (2017). Identification of Key Proteins and Pathways in Cadmium Tolerance of Lactobacillus Plantarum Strains by Proteomic Analysis. Sci. Rep. 7, 1182. doi:10.1038/s41598-017-01180-x

Conflict of Interest: The authors declare that the research was conducted in the absence of any commercial or financial relationships that could be construed as a potential conflict of interest.

Publisher's Note: All claims expressed in this article are solely those of the authors and do not necessarily represent those of their affiliated organizations, or those of the publisher, the editors and the reviewers. Any product that may be evaluated in this article, or claim that may be made by its manufacturer, is not guaranteed or endorsed by the publisher.

Copyright () 2021 Muhammad, Ramzan, Zhang, Zhao, Gul, Dong and Zhang. This is an open-access article distributed under the terms of the Creative Commons Attribution License (CC BY). The use, distribution or reproduction in other forums is permitted, provided the original author(s) and the copyright owner $(s)$ are credited and that the original publication in this journal is cited, in accordance with accepted academic practice. No use, distribution or reproduction is permitted which does not comply with these terms. 